\title{
Minority Education in Engineering, Mathematics and Science
}

\author{
Joseph D. Torres and Tom Cummings \\ School of Engineering \\ University of New Mexico
}

\begin{abstract}
The University of New Mexico (UNM) Minority Engineering, Mathematics and Science (MEMS) Program is a uniquely comprehensive program designed to increase the number of minority students enrolling, graduating and pursuing careers in Engineering, Mathematics and Science (EMS) by: 1) improving retention rates of students in EMS disciplines, 2) fostering relations with industry and the technical community to address workforce needs and professional development of EMS students, and 3) enhancing public teachers' ability to teach mathematics, science and technology. The program has developed several collaborative initiatives/partnerships with two-year post-secondary institutes statewide and with public schools for the purposes of increasing the participation rate of New Mexicans in post-secondary education by increasing the number of statewide public schools that participate in these collaborative efforts.
\end{abstract}

\section{Introduction}

The MEMS recruitment and retention program consists of seven core components: I) A Summer Bridge Program, for 50 topnotch high-school students admitted and planning to enroll at UNM in the Fall. This intensive four-week program prepares them for the UNM environment, fosters community among participants, encourages academic excellence, improves retention rates, provides students with academic success strategies, bridges the gap between high school and college, and acquaints incoming freshmen with faculty and the university environment. II) MEMS Academic Excellence Workshops (AEW)/study groups, in core courses for EMS majors, create a community environment based on academic excellence and help participants improve their networking, problem-solving and presentation skills, and academic performance. III) Scholarships funded by industry and the federal government. Scholarship recipients are required to co-op and/or intern with sponsors. IV) Undergraduate Research Experiences allow university students to do meaningful research with faculty mentors in their areas of interest. Students begin to understand how what they have learned in the classroom actually applies to the real world preparing and motivating them to consider graduate school. V) Pre-College Activities and Teacher Training. MEMS has been involved in the support, design, development and implementation of various projects to encourage pre-college students to consider careers in engineering, mathematics and science. Its teacher training programs are designed to increase the pool of well-qualified mathematics and science teachers and to assist teachers in developing effective strategies for teaching math, science and technology. VI) The AMP SIPI, T-VI, UNM Valencia and UNM Los Alamos collaborations are funded by the National Science Foundation's (NSF) Alliance for Minority Participation (AMP) to increase the number of EMS students transferring from two to four-year institutes. VII) The Rio Grande and Valley Cluster Programs are partnerships with the Valley and Rio Grande clusters designed to increase the number of 
students entering college in EMS disciplines. Each cluster consists of a high school and all the elementary and middle schools feeding into that high school.

For purposes of brevity, this paper will focus mostly on the Summer Bridge Program, MEMS AEW's, the Rio Grande/Valley cluster programs and the AMP SIPI, T-VI, UNM Valencia and UNM Los Alamos collaborations. Only components of the other programs that provide direct support activities for these programs will be discussed. The AMP SIPI, T-VI, UNM Valencia and UNM Los Alamos collaborations are one of MEMS' newer projects; goals and problems associated with this project will be discussed at length.

\section{Background Information}

This section will provide a fairly detailed summary of the initial information that was gathered and analyzed in order for MEMS staff to understand the needs and problems that minority engineering students face at UNM. This type of analysis is a necessary element in the design of effective retention strategies, activities and programs.

New Mexico's ranks $50^{\text {th }}$ in the nation for per capita median household money income ${ }^{1}$ and it ranks $1^{\text {st }}$ for percentage of persons living below poverty level ${ }^{1}$. Its public high school graduation rate is $39^{\text {th }}$ among the 50 states $^{2}$. It ranks $37^{\text {th }}$ in the proportion of its 19 year-olds enrolled in college immediately after high school ${ }^{2}$ and $49^{\text {th }}$ in the percent of students from low income families enrolled in college 2 . Only $49.7 \%$ of New Mexico college students are enrolled fulltime $^{1}$. Although $53 \%$ of the population is minorities ${ }^{3}$, only 19 percent of its professionals are minorities ${ }^{4}$. In 1997-1998, at the state's research universities, only 33.9 percent of undergraduate students receiving BS degrees in engineering, mathematics and science were minority ${ }^{5}$. The expenditure of state funds for higher education per $\$ 1,000$ of personal income is the second highest among the states ${ }^{2}$. The tuition and fees of its public post-secondary institutions are among the lowest in the country, $46^{\text {th }}$ among the states ${ }^{2}$. At the University of New Mexico (UNM), 64\% of undergraduates qualify for financial aid under the eligibility requirements for the U.S. Department of Education Pell Grant ${ }^{6}$ and $41 \%$ of graduate students receive financial aid $^{6}$. In all UNM surveys given over the past 10 years, formal or informal, the number one reason that students cite for dropping out is financial. It is evident that financial need must be addressed in the development of any effective retention strategy for native New Mexicans.

An equally important issue that must be addressed is that of academic preparation. In the following study, we refer to Hispanic, Native American and African American as underrepresented ethnic minorities due to their poor representation in EMS disciplines. Since statistically, we find that Asians perform on a par with Whites in the area of academicpreparation, we will group them together. Our comparison groups for the following study will

\footnotetext{
${ }^{1} 1996$ US Census Bureau

${ }^{2}$ New Mexico Legislative Finance Committee report, Thomas G. Mortenson, December 17, 1998

${ }^{3}$ July 1, 1997 US Census Bureau Annual Time Series of State population estimates

${ }^{4} 1990$ New Mexico Department of Labor Report to Governor Bruce King

${ }^{5}$ Data Source: New Mexico Commission on Higher Education

61999 UNM Financial Aide Annual Report
} 
Figure 1. Fall 1997 Incoming Freshman Math-ACT Scores

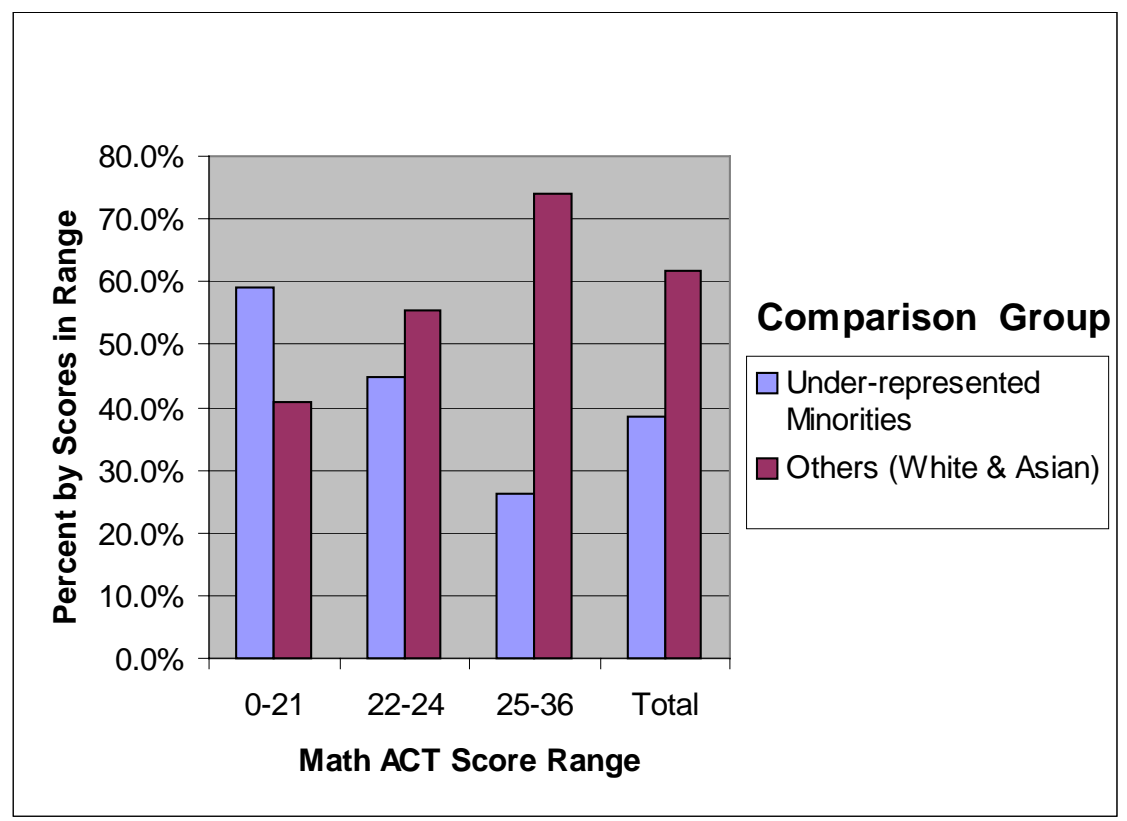

Figure 2. Fall 1997 Incoming Freshman Math-ACT Scores

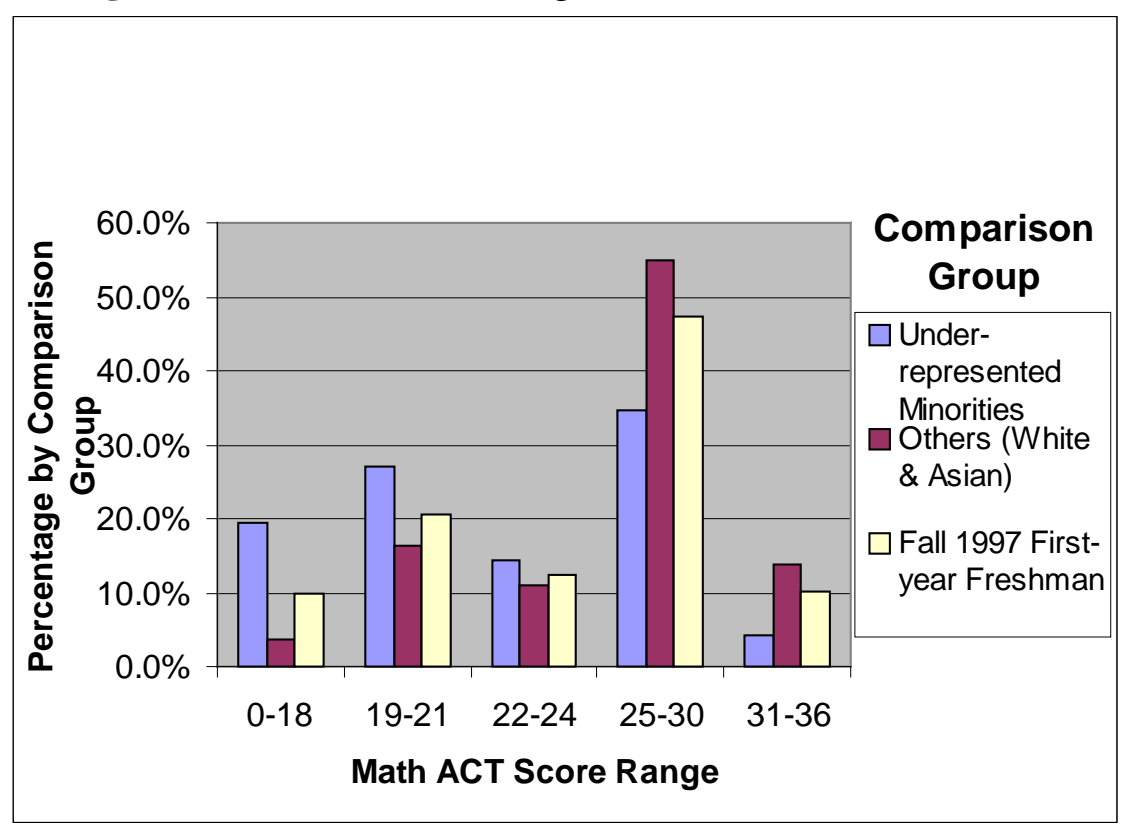

be comprised of these two groups. The actual breakdown of these ethnic groups in the UNM School of Engineering (SOE) at the time of this study was: 58\% white; $3.6 \%$ Asian; $26.1 \%$ Hispanic; $8.5 \%$ Native American; and 3.9\% African American.

In this study, we use MathACT scores, with some interpretation, to determine the academic preparation of our two comparison groups. We use Math-ACT scores of 21 and 25 as cutoff scores, since students who achieve lower than 21 are generally required to enroll in remedial or developmental math courses prior to entering into the engineering curricula and students achieving higher than 25 generally are fairly well prepared to enter into the engineering curricula without much remedial work.

For Fall 1997, at the University of New Mexico; $61.6 \%$ of incoming freshman engineering students were White or Asian; $\quad 38.4 \%$ were Hispanic, Native American, or African American. Yet, we found that a disproportionate percentage $(59.1 \%)$ of these students, with Math-ACT scores lower then or equal to 21, were under-represented ethnic minorities; only $40.9 \%$ of those, achieving scores lower then or equal to 21 , were Whites and Asians (See Figure 1). Moreover, Figure 1 shows that a disproportionate number of underrepresented ethnic minorities fail to achieve high Math-ACT scores; only $26.1 \%$ of under- 
represented ethnic minorities achieve scores greater than or equal to 25 as compared to $73.9 \%$ of Whites and Asians.

The actual percentage of Fall 1997 incoming freshman engineering under-represented ethnic minorities achieving scores lower then or equal to 21 was $46.6 \%$, whereas, only $20.1 \%$ of Whites and Asians fall into this category. If we look at the top achievers on the Math-ACT tests at UNM, we find $13.8 \%$ of Whites and Asians achieved scores greater than 31 as opposed to $4.2 \%$ of under-represented ethnic minorities. At the other extreme, $19.5 \%$ of under-represented ethnic minorities as opposed to $3.7 \%$ of Asians and Whites achieve below 18 on the Math-ACT (see Figure 2, above).

Math ACT scores are only one indicator of academic preparation. By themselves they do not give much information other than how capable a student is of preparing for a test of that magnitude. But coupled with high school ranking, performance and historical information; they can give a clear picture of an individual student's academic preparation. Every study on the academic preparation of under-represented minorities in New Mexico, over the past 20 years, independent or otherwise and regardless of what variables are used (i.e. dropout, GPA, ranking, ACT scores, number of students taking honor courses, number taking advanced placement tests, etc...), indicates that a big disparity in academic preparation for these students versus others does exist.

Let us emphasize that this analysis provides information on academic preparation of freshman engineering students and makes no attempt to define a means for predicting potential for success (i.e. potential or ability to get a bachelors degree in an engineering, mathematics or science discipline); in fact, it is doubtful that any such mechanism exists. What we do find is that underrepresented minority populations come to UNM with less academic preparation than White and Asian populations.

Other factors that impact minority education and retention are typical of large institutions. In an informal survey, engineering students cited additional factors for poor retention within the UNM School of Engineering: lack of community, inadequate peer support, lack of comfort participating in activities associated with the university (such as study groups, office hours for faculty, etc.), and lack of direction, enthusiasm or motivation. This, coupled with a lack of good study skills; low faculty involvement; and low expectations from friends, family and teachers, causes many minority students to fail or leave college.

\section{Overview of Program Goals}

The goals and objectives for the MEMS project were developed after careful analysis and consideration of the needs and problems of minority engineering students outlined in Section II. The main goal of this program is to develop academic success strategies for minority and lowincome students to enable them to pursue baccalaureate degrees in engineering, mathematics or science and to cultivate outside funding sources to provide financial assistance in the form of scholarships, co-ops, internships and employment. The expected outcomes for the MEMS project are:

- Improved education for students in the stated disciplines, 
- Increased retention of students to BS degree achievement in the stated disciplines,

- Improved professional development and employment/further higher education placement of participating students,

- Strengthened partnerships between institutions of higher education and related industry/government employment sectors,

- Strengthened relationship between workplace needs and academic programs, and

- Enhanced ability for public school teachers' to teach mathematics, science and technology.

Our vision is to graduate engineering, mathematics and science students who are motivated, have good work ethics and serve as role models in their own communities, and to achieve this in an extended community environment that fosters academic excellence.

IV. Program Components

In order to address the concerns and achieve the goals cited in Sections II and III, the MEMS program at UNM has developed a comprehensive program:

- To foster community in an environment of academic excellence,

- To cultivate academic success strategies in its students, and

- To provide opportunities for professional development, such as; internships, co-ops and undergraduate research positions.

The program is designed to address the financial and academic needs of minority and lowincome students. Low-income students are a natural fit for this program since financial need and inadequate academic-preparation often go hand-in-hand. This section provides an overview of MEMS activities and program components.

Summer Bridge. Every year since summer 1994, 40 to 50 graduating high school seniors who have been accepted to UNM in engineering, math or science programs participate in the MEMS Summer Bridge program at no cost to the student. Because of financial need, many students within our target population would not be able to attend if there were a charge or cost associated with the program. In 1999, 69.7\% of summer bridge students were financially needy; the average annual financial need of summer-bridge students was $\$ 8374$.

Until now, 255 students have participated in this intensive, four-week program that transitions under-represented minority high school students to university life. It is designed to prepare students for the rigors of academic life at UNM, acquaint them with the UNM community, teach them academic success strategies and instill in them a feeling of community.

Students take two courses for credit: an applied mathematics course from 8:00AM to 12:00 Noon on Monday, Wednesday and Friday and an English course from 8:00AM to 12:00 Noon on Tuesday and Thursday. They participate in hands-on engineering design, math or science workshops from 1:30PM-3:00PM and hands-on computer science workshops from 3:00PM5:00PM every weekday. They have free time in the afternoon and weekends for athletics and other recreational activities. From 8:00PM to 10:00PM, Monday through Thursday, and 5:00PM to 9:00PM on Sunday they attend Academic Excellence Workshop study groups for their 
Mathematics and English classes. A typical weekly calendar of events for the MEMS Summer Bridge is included in Table 1, below.

Table 1. Typical Week in the MEMS Summer Bridge Program

\begin{tabular}{|c|c|c|c|c|c|c|}
\hline Sunday & Monday & Tuesday & Wednesday & Thursday & Friday & Saturday \\
\hline $\begin{array}{l}\text { 5:00PM to } \\
\text { 8:00PM Math } \\
\text { Study Group }\end{array}$ & $\begin{array}{l}\text { 8AM to 12Noon } \\
\text { Math } \\
\text { 1:30PM to 3PM } \\
\text { Fluid Dynamics } \\
\text { 3:30PM to 5PM } \\
\text { Computer } \\
\text { Science } \\
\text { 8PM to 10PM } \\
\text { English Study } \\
\text { Group }\end{array}$ & $\begin{array}{l}\text { 8AM to } 12 \text { Noon } \\
\text { English } \\
\text { 1:30PM to 3PM } \\
\text { Fluid Dynamics } \\
\text { 3:30PM to 5PM } \\
\text { Computer } \\
\text { Science } \\
\text { 8PM to 10PM } \\
\text { Math Study } \\
\text { Group }\end{array}$ & $\begin{array}{l}\text { 8AM to } 12 \text { Noon } \\
\text { Math } \\
\text { 1:30PM to 3PM } \\
\text { Structural } \\
\text { Dynamics } \\
\text { 3:30PM to 5PM } \\
\text { Computer } \\
\text { Science } \\
\text { 8PM to 10PM } \\
\text { English Study } \\
\text { Group }\end{array}$ & $\begin{array}{l}\text { 8AM to 12Noon } \\
\text { English } \\
\text { 1:30PM to 3PM } \\
\text { Bridge Design } \\
\text { 3:30PM to 5PM } \\
\text { Computer } \\
\text { Science } \\
\text { 8PM to 10PM } \\
\text { Math Study } \\
\text { Group }\end{array}$ & $\begin{array}{l}\text { 8AM to } 12 \text { Noon } \\
\text { Math } \\
\text { 1:30PM to 3PM } \\
\text { Bridge Design } \\
\text { 3:30PM to 5PM } \\
\text { Computer } \\
\text { Science } \\
\text { 8PM to 10PM } \\
\text { English Study } \\
\text { Group }\end{array}$ & $\begin{array}{l}11 \mathrm{AM} \text { to } 3 \mathrm{PM} \\
\text { Picnic \& } \\
\text { Geology Field } \\
\text { Trip }\end{array}$ \\
\hline
\end{tabular}

The mathematics course is taught in a collaborative and cooperative learning environment. The math class is broken up into groups with six to seven students in each group; each group is assigned a math AEW facilitator as team leader. The team leader is responsible for the grading and tracking of the group. This allows the instructor to keep close tabs on individual student progress. Applied mathematics and problem solving is emphasized in the class.

Figure 3. Sample Problem for Summer Bridge Applied Mathematics Class

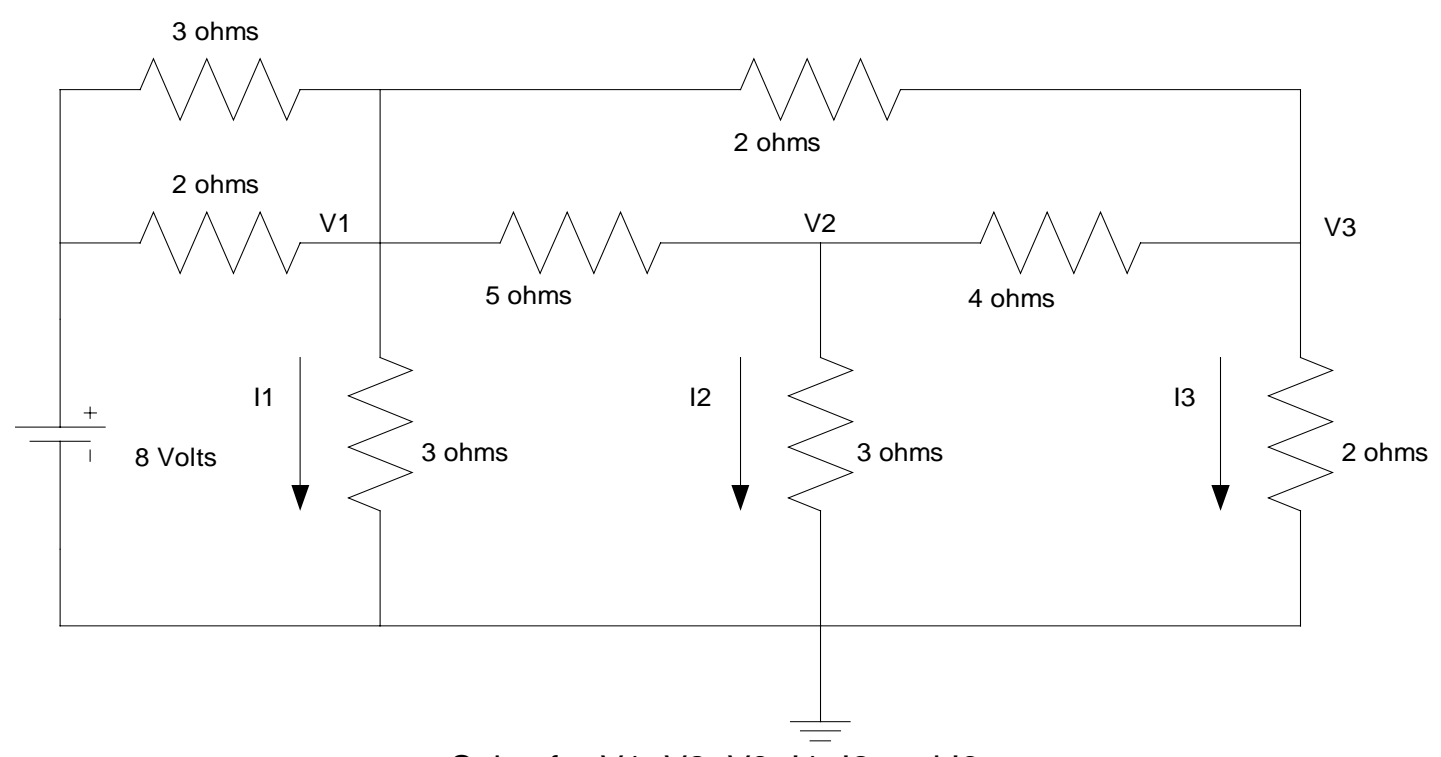

Solve for V1, V2, V3, I1, I2 and I3.

The topics for the mathematics course are: Pre-Calculus, Applied Problem Solving and Applied Matrix Theory. Many of the problems for the course are selected from freshman and sophomore 
engineering texts. Figure 3, above, is an example of a typical circuits problem given to MEMS Summer Bridge students at the end of the Applied Matrix Section of the course.

UNM faculty and professional engineers from industry teach the hands-on workshops. Every year since Summer 1994, Dr. Kenneth Kraft from Lucent Technologies, gives a one-week workshop in which students study, design and put together a radio. Dr. Gerstle, faculty in the Department of Civil Engineering at the University of New Mexico, teaches basic Structural Engineering concepts and, based on these concepts, conducts a Bridge Building contest (in Figure 4, below, students prepare for this contest). Additional hands-on workshops are provided

Figure 4. Preparation for Bridge Building Contest

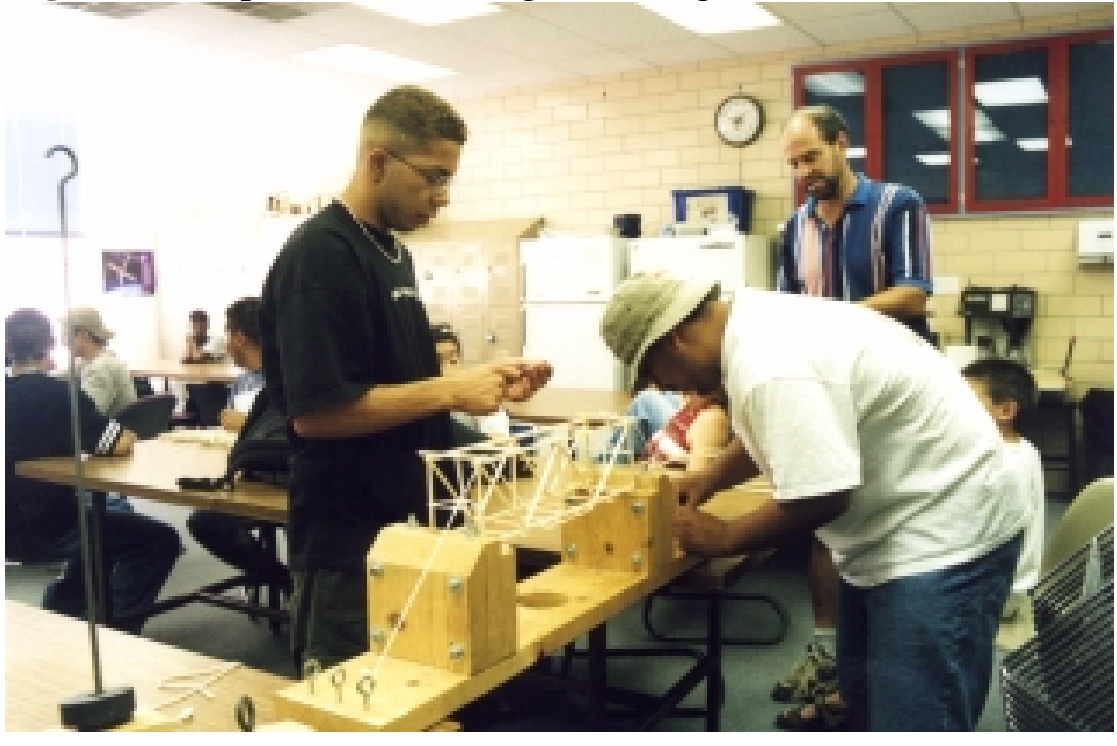

Figure 5. MEMS Summer Bridge Math AEW

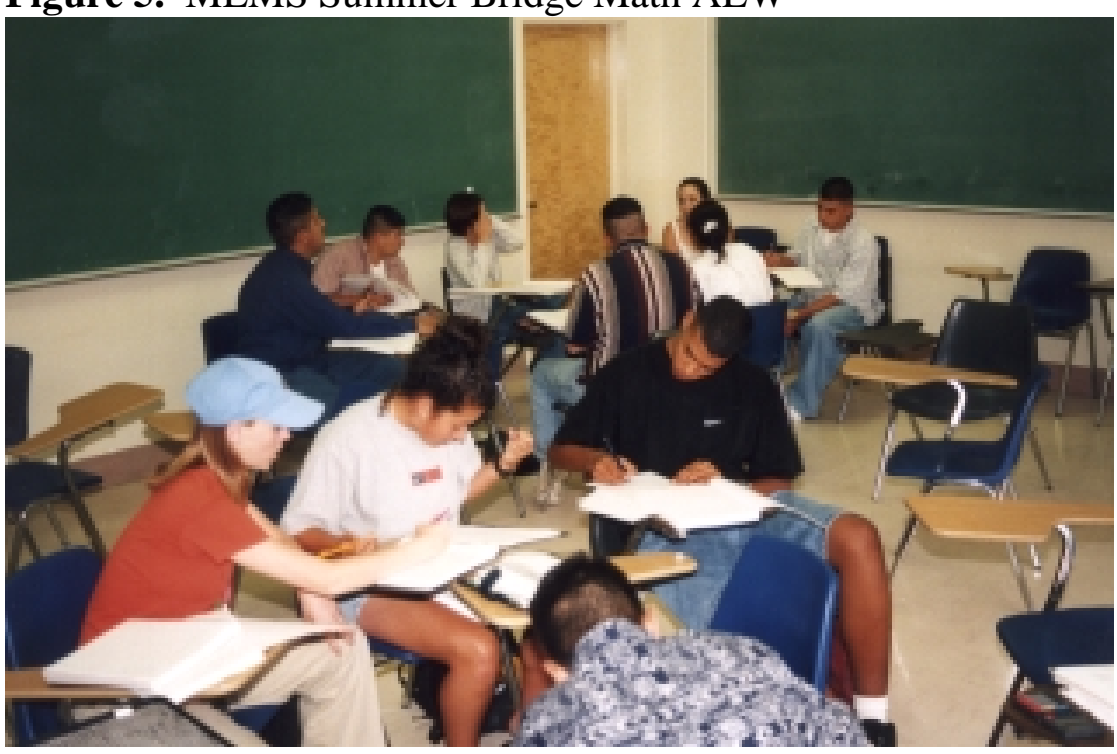

in: lasers, chemical engineering, Fluid Dynamics, Structural Dynamics, Biology and Physics.

In the English class, expository writing is emphasized to help students develop their writing skills and to give them extra practice writing. Every year, students pick one paper to perfect for publication in an anthology at the end of the program.

The MEMS Summer Bridge provides many opportunities for students to bond with each other such as picnics, recreational activities, AEW study groups, etc... (in Figure 5, students work on homework during an AEW study group, in Figure 6, below, students enjoy each others' company during a MEMS sponsored picnic). Most MEMS summer bridge proctors, mathematics and English AEW facilitators, and student support staff are 
previous summer bridge participants, a part of a larger peer-support network that participants can rely on. In exit surveys of participants, the number one benefit citied is the opportunity to have a group of 50 other students who are friends who they see in classes and at other events on a regular basis long after summer bridge is over.

Students who participate in the MEMS Summer Bridge program outperform other engineering, math and science

Figure 6. Summer Bridge Students Playing Cards at a Picnic

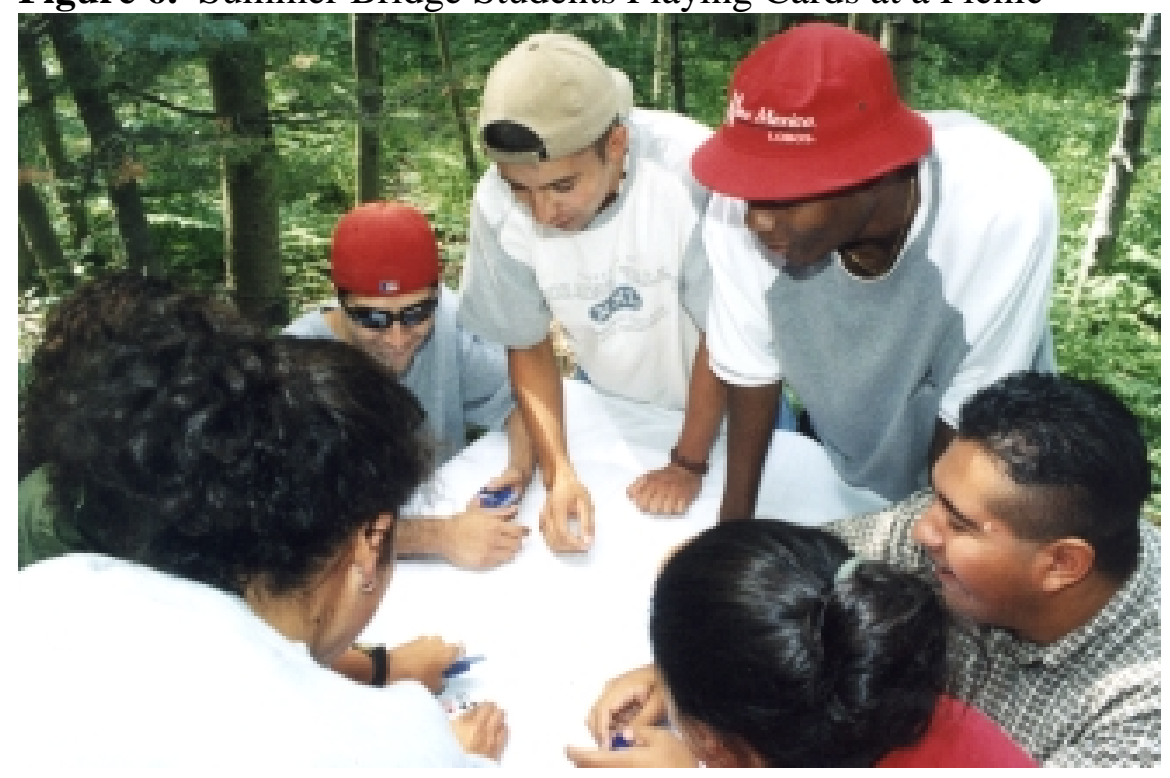

students in academic performance as well as retention. For instance, after four years, the MEMS 1995 Summer Bridge students were retained at $73 \%$ as opposed to $51 \%$ of the 1989 incoming freshman engineering class and $50 \%$ of the 1989 incoming minority freshman engineering class that was used for baseline data (see Figure 7).

This happens in spite of the large number of

Figure 7. MEMS Comparison Data

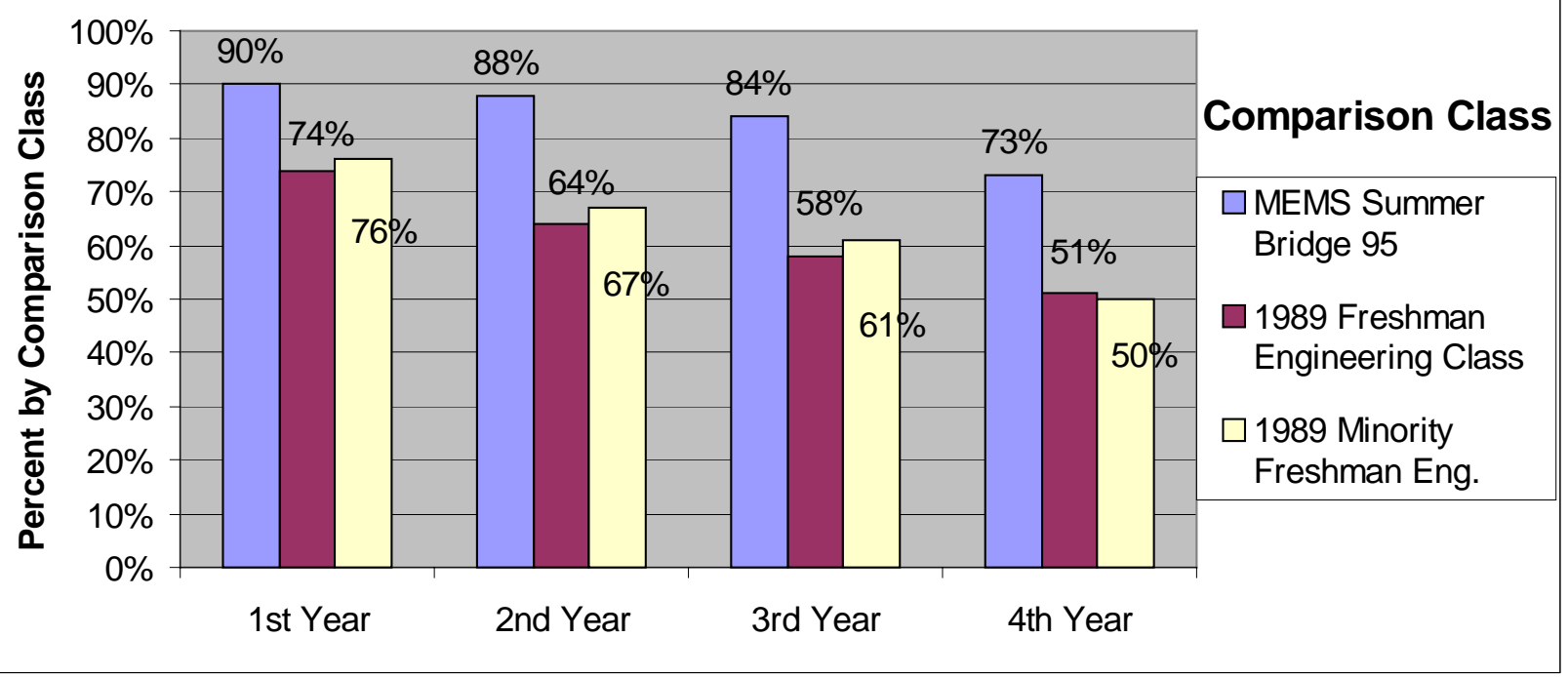


summer bridge participants with low Math ACT scores: $22.6 \%$ achieved scores below 18; $51.6 \%$ achieved scores below 21; 67.7\% achieved below 25; and the average Math ACT Score for these students was 22 .

MEMS Academic Excellence Workshops/ Study Groups. AEW study groups are designed to create peer-support groups among minority and low-income engineering, mathematics and science students. Recently, MEMS has expanded the target population for its AEW's to include probation, at-risk and marginally performing students. AEW's are designed to keep students on

Figure 8. Students discussing a problem in AEW Workshop

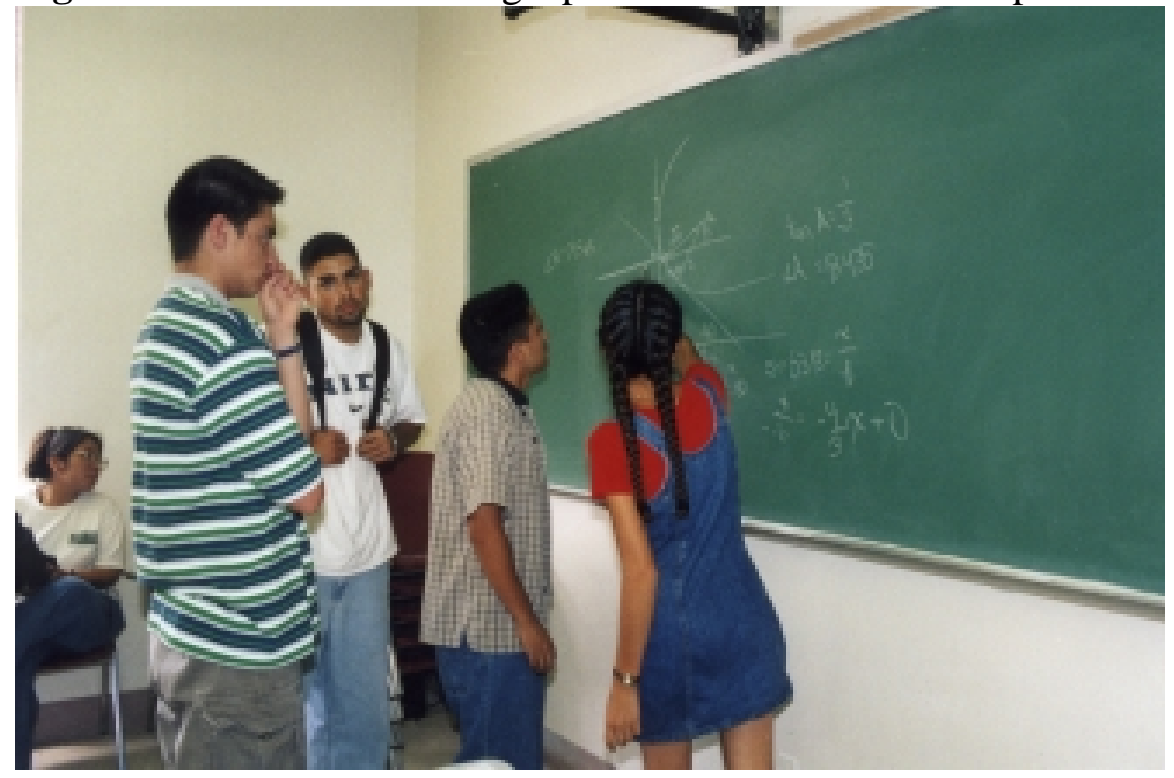

Figure 9. Students use AEW Workshops to Prepare for Exams

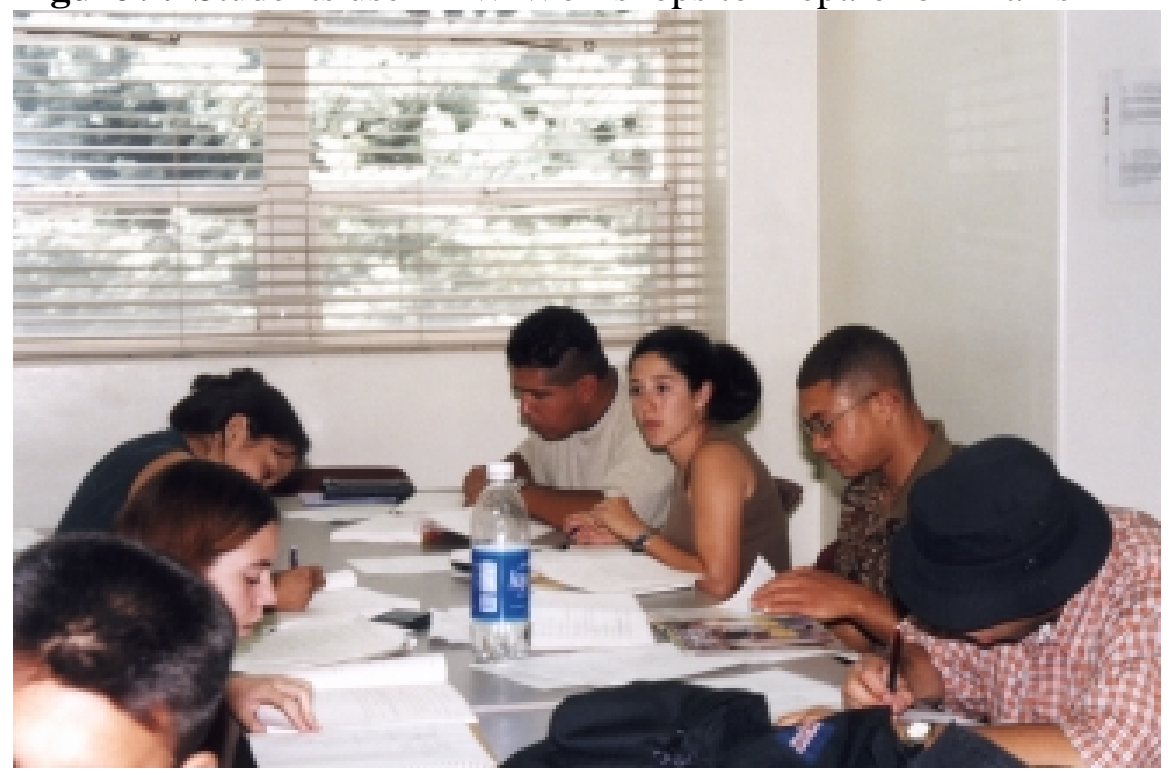

task, studying longer in an environment that they enjoy, networking with each other to solve problems, and developing a comfort zone and networking with MEMS staff (in Figures 8 and 9, students use AEW study groups to discuss problems and prepare for exams). Participants have the opportunity to develop and improve their study skills in an encouraging and supportive environment. Our experience shows that a strong peer support group is one factor in retention. Many of the MEMS students quickly find that their peers are their best and most reliable resource for getting homework done and keeping up with course materials.

The MEMS AEW's are based on the models developed by Ray Landis, Dean of Engineering, California State at Los Angeles and Uri Treisman, University of Texas at 
Austin. Their intention is to design a learning environment to enhance the undergraduate experience by providing a structured learning atmosphere that emphasizes the development of critical thinking through the use of cooperative and collaborative learning techniques. MEMS provides training seminars, based on Landis' and Treisman's research, for all MEMS staff and facilitators associated with AEW study groups.

The MEMS AEW's are facilitated by graduate or advanced undergraduate students who work with AEW participants to challenge them to
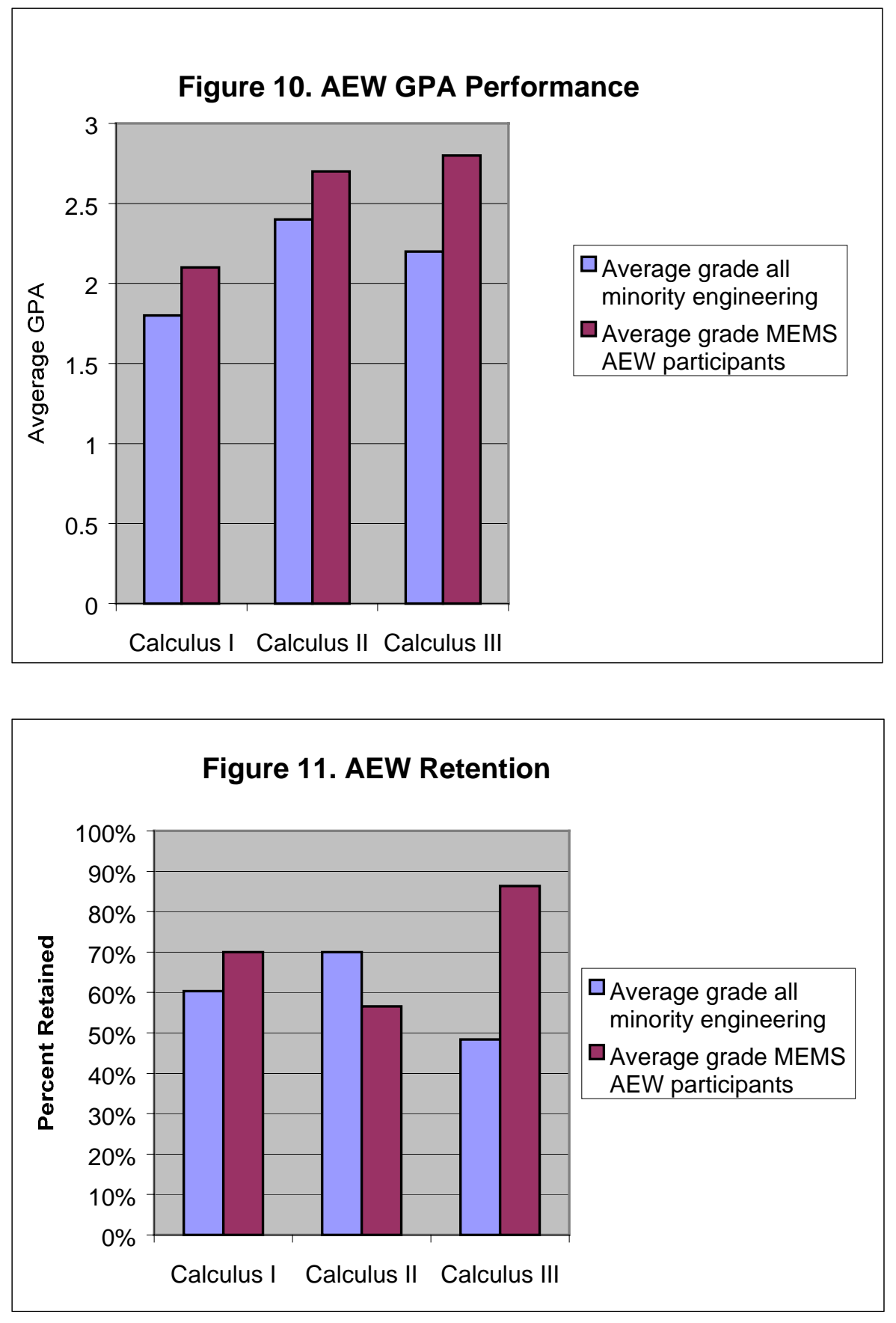
work cooperatively and collaboratively to solve problems similar to those from class work and homework. The facilitators do not use assigned homework problems, but similar or more difficult problems to stimulate the students into thinking and trying various approaches until they arrive at their solutions. This approach encourages the students to work as team members and to think creatively. Students develop high expectations of themselves and of others as they progress to more difficult problems.

In spite of the proven successes of AEW's, it is difficult to get students to attend without incentives. Students cite the following reasons for not attending study groups: need to work, prefer to study alone and AEW's interfere 
with other activities such as child-care. This can be overcome by creating incentives for students to use AEW's. For Spring and Fall 1999, 183 students received government and corporate sponsored scholarships and stipends from MEMS. Every student who receives a scholarship or stipend from MEMS is required to enroll in Engineering 116 (a general course used to give AEW participants credit for their participation) for two consecutive semesters. Students in this course are required to attend 9 hours of AEW study groups every week. About $36 \%$ of MEMS scholarships and stipends are awarded to probation, at-risk or marginally performing students (65 out of 183). As a result of these efforts, 207 students used MEMS AEW's in the Fall of 1998 and 148 in the Spring of 1999.

Table 2. MEMS AEW Study Groups

\begin{tabular}{|c|c|c|c|c|}
\hline & $\underline{\mathrm{DAY}}$ & $\underline{\text { TIME }}$ & $\underline{\text { PLACE }}$ & $\underline{\text { FACILITATOR }}$ \\
\hline \multicolumn{5}{|l|}{ MATH STUDY GROUPS } \\
\hline Trigonometry/Algebra (Math 123/150) & M W F & $2 \mathrm{pm}-4 \mathrm{pm}$ & Centennial L283 & Vince Padilla \\
\hline \multirow[t]{7}{*}{ Calculus I (MATH 162) } & M W F & $9 \mathrm{am}-10 \mathrm{am}$ & Eng-X 201 & Jessica Nelson \\
\hline & M W & $11 \mathrm{am}-1 \mathrm{pm}$ & Eng-X 201 & Markin Demsey \\
\hline & M W F & $1 \mathrm{pm}-2 \mathrm{pm}$ & Eng-X 201 & Jessica Nelson \\
\hline & MW F & $2 \mathrm{pm}-4 \mathrm{pm}$ & Eng-X 201 & Kathyern Martinez \\
\hline & M W F & $4 \mathrm{pm}-7 \mathrm{pm}$ & Eng-X 202 & Markin Demsey \\
\hline & T Th & $2 \mathrm{pm}-4 \mathrm{pm}$ & Engr-X 201 & Ira Strain-Bey \\
\hline & Sat & $1 \mathrm{pm}-4 \mathrm{pm}$ & MH 120 & Joe Torres, Luis Gut. \\
\hline \multirow[t]{5}{*}{ Calculus II (MATH 163) } & M W F & 9am-10am & Eng-X 201 & Jessica Nelson/Jorge \\
\hline & MW F & $2 \mathrm{pm}-4 \mathrm{pm}$ & Eng-X 202 & Chris Miles \\
\hline & MW F & $4 \mathrm{pm}-7 \mathrm{pm}$ & Eng-X 202 & Jorge Rincon \\
\hline & $\mathrm{T} \mathrm{Th}$ & $2 \mathrm{pm}-4 \mathrm{pm}$ & Engr-X 201 & Luis Gutierrez \\
\hline & Sat & $1 \mathrm{pm}-4 \mathrm{pm}$ & MH 120 & Joe Torres, Luis Gut. \\
\hline Calculus III (MATH 264) & T Th & $2 \mathrm{pm}-4 \mathrm{pm}$ & WAGNER 235 & Mario Delgado \\
\hline Differential Equations (MATH 316) & T Th & $4 \mathrm{pm}-6 \mathrm{pm}$ & Eng-X 201 & Toby Townsend \\
\hline \multicolumn{5}{|l|}{ PHYSICS STUDY GROUPS } \\
\hline Physics I (PHYSCS 160) & T Th & 2:00-6:00pm & Regener 111 & Ryan Dixon \\
\hline Physics II (PHYSCS 161) & M W F & 2:00-4:00pm & Regener 111 & Juan Marcelo \\
\hline Physics III (PHYSCS 262) & MW F & 4:00pm-6:00pm & Regener 111 & Juan Marcelo \\
\hline Physics Office Hours M W F & 1:00pm-2:00pm & Engr-X 209 & Juan Marcelo Cabrera & \\
\hline \multicolumn{5}{|l|}{ COMPUTER SCIENCE STUDY GROUPS } \\
\hline $\mathrm{C}++(\mathrm{CS} 151)$ & M W F & $4 \mathrm{pm}-6 \mathrm{pm}$ & Engr-X 209 & Jonathan Atencio \\
\hline \multirow[t]{2}{*}{ CHEMISTRY TUTOR } & Phone: 232-9385 & by arrangement also & Toby Townsend & \\
\hline & MW F & 9:00-10:00AM & Engr-X 208 & Toby Townsend \\
\hline \multirow[t]{2}{*}{ Chem 122} & By arrangement & & Candice Williamson & \\
\hline & $\mathrm{T}$ Th & 1:00-2:30PM & Engr-X 208 & Candice Williamson \\
\hline \multicolumn{5}{|l|}{ ENGINEERING STUDY GROUPS } \\
\hline Statics (CE 202) & $\mathrm{T}$ Th & $2 \mathrm{pm}-4 \mathrm{pm}$ & Centennial L283 & Chris Miles \\
\hline Dynamics (ME 306) & MW F & $4 \mathrm{pm}-6 \mathrm{pm}$ & Engr-X 201 & Marco Romero \\
\hline Circuits I (EECE 203) & T TH & $4 \mathrm{pm}-6 \mathrm{pm}$ & Centennial L283 & Mark Dixon \\
\hline Computer Logic Design (EECE 238) & MW F & $2 \mathrm{pm}-4 \mathrm{pm}$ & M H 217 & Tu-Trung Ong \\
\hline Thermodynamics (ME 301) & $\mathrm{T}$ Th & $4 \mathrm{pm}-6 \mathrm{pm}$ & Wagner 235 & Rafael Arauz \\
\hline $\mathrm{C}++(\mathrm{CS} 251)$ & T Th & 9:00am-11:00am & Engr-X 209 & James Cajete \\
\hline \multicolumn{5}{|l|}{ BIOLOGY STUDY GROUPS } \\
\hline Biology 121 & T Th & $7-9$ & Biology $163 \mathrm{C}$ & Jose Weber \\
\hline Biology 122 & T Th & 3:30pm-5:30pm & M H 107 & Rebecca McIntosh \\
\hline \multicolumn{5}{|l|}{ Miscellaneous } \\
\hline English (AISTEC) & M W & $1 \mathrm{pm}-2 \mathrm{pm}$ & WAGNER 235 & Katie Yazzie \\
\hline
\end{tabular}


Figures 10 and 11, above, for Spring 1999 are examples of data collected on AEW performance at the end of each semester. This data allows us to troubleshoot and to assess the overall AEW performance. Figure 10 demonstrates that AEW participants outperformed all other minority students in GPA. Figure 11 shows that Calculus I and III AEW students were retained better than other minority engineering students taking the same classes. The fact that retention in Calculus II was low led MEMS staff to an informal survey in which MEMS AEW students cited class-scheduling conflicts as a major reason for poor attendance in the Calculus II AEW. Many students were only able to attend the AEW for less than two hours per week. For Fall 1999, we addressed the problem by increasing the number and hours that the calculus II AEW's are run from 6 hours per week to 29 hours per week. All things considered, we feel that AEW's do very well bearing in mind that AEW's serve a large number of probation, at-risk or marginally performing students (about 36\%). Table 2, above, lists many of the study groups offered by the MEMS project.

AEW's are a good way to provide additional financial assistance in the form of hourly wages to undergraduate and graduate AEW facilitators. This often allows them to quit other jobs not relevant to their majors and to focus on their university studies. Currently, MEMS conducts AEW's for 16 key gateway courses in engineering, mathematics and science; 22 students are funded by MEMS to facilitate study groups.

The MEMS AEW study groups are critical to the process of encouraging collaboration and community among freshman minority engineering students. In an informal survey, students cited the following as benefits of attending AEW's:

- A good way for students to interact with each other and to network,

- Attending study groups is a good way to get homework done on time,

- Helps develop study skills,

- Explaining material to others is a good way to learn the material, and

- Helps with time management.

Scholarships. At a university with such a high percentage of low-income financially needy students, scholarships must be the backbone of any effort to increase the retention and graduation rates of under-represented ethnic minorities. From experience, we have found that scholarships are not enough; that, without other retention activities in place such as the MEMS Summer Bridge Program and AEW study groups, an unnecessarily large percentage of these students will loose their scholarships due to poor academic performance. Ultimately, there will be no noticeable impact on improved retention rates.

The MEMS program uses scholarships to provide an incentive for students to become involved in activities that can dramatically impact the quality of education and ultimately serve as a mechanism to improve their chances for success at UNM. Currently, 183 students receive scholarships and stipends from the MEMS project. All MEMS scholarship recipients are required to enroll in Engineering 116 (currently is used for mathematics and science students as well as engineering students since a similar class for these students does not exist in the College of Arts and Sciences) for the first two semesters after receiving a scholarship from the MEMS program. The main purpose of the course is to give AEW study group participants official university credit for their participation. Participants are required to log at least 9 hours per week 
of AEW study groups every week for the duration of the course. Students can take the course over as many times as they like.

In the Spring of 1999, 86 MEMS scholarship students participated in the Engineering 116 course; the average semester GPA for participants was 2.98 for Spring 1999. This is very good considering that the average semester GPA for these same students was 2.82 for Fall 1998. This Fall 1999, 110 scholarship students are taking the course.

Many private, corporate and government agencies sponsor scholarships for MEMS undergraduate engineering, mathematics and science students. Most sponsoring agencies require their scholarship recipients to do a co-op or internship if offered. Co-ops and internships are an excellent way for students to become familiar with what engineers, mathematicians and scientists do. Performance, motivation, enthusiasm and attitude of students generally improve after a coop or internship.

Undergraduate Research Experiences. An Undergraduate Research Experience (URE) is a paid position for an undergraduate student to do a meaningful research project under faculty mentorship. It is the most effective way to link students with faculty in their areas of interest. The main goal of the URE project is to provide a more meaningful education than the standard lecture style learning that goes on in university classrooms and to encourage and motivate students to go on to graduate school by giving them the opportunity to experience graduate level research. Some of the objectives of the URE program are to help students become comfortable with faculty, with the UNM academic and research culture, and to gain an understanding of academic research.

From September 1994 to December 1996, MEMS piloted an undergraduate research project funded by the Department of Defense (DoD) for students majoring in EMS disciplines. During this period, MEMS awarded a total of 60 URE's. We found that $88.3 \%$ of these students have graduated with Bachelors degrees with an average GPA of 3.26. Three of the students are still in school and will graduate in May 2000. At least 15 (25\%) of these students have gone on to graduate school; we suspect that this number is much higher but did not have a mechanism in place for gathering exit information from all students at that time.

Each semester, MEMS has 10 URE slots available where students work directly under faculty supervision in a broad variety of engineering and science subjects. Some of the projects students work on are: robot sensor fault detection; computer-based quantitative geomorphic analysis; small-scale hydrology of fractured sandstone samples; environmental bio-sensor stabilization; and computerized sorting and analysis of raw ecological data.

Recently, UNM received an award from NASA to increase the number of students in URE positions. Under this project, UNM is now able to provide around 50 URE's, annually, to engineering, mathematics and science students.

Pre-College Activities and Teacher Training. Because of poor academic preparation of minority students in New Mexico (See Section II, above), MEMS has developed and become involved in various pre-college initiatives. These pre-college and teacher training activities serve 
Figure 12. Student from Saturday Math and Science Academy Working on Model Rocket

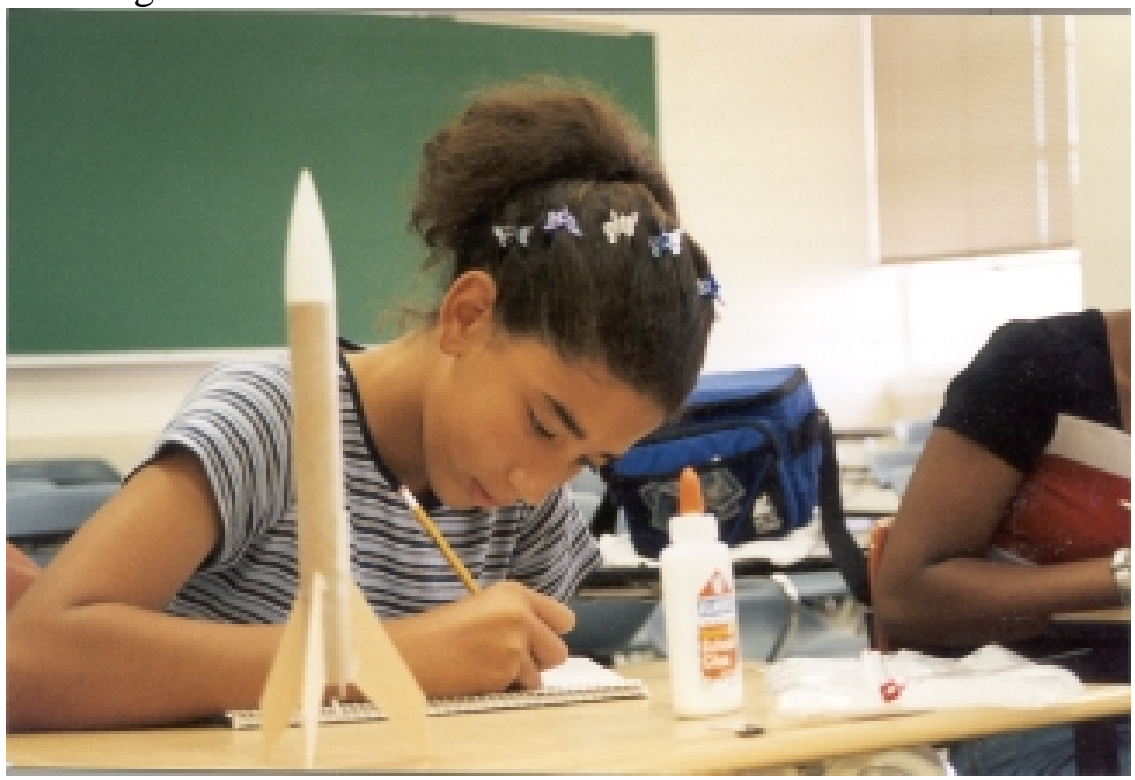

Figure 13. Student from Saturday Math and Science Academy Working on Model Rocket

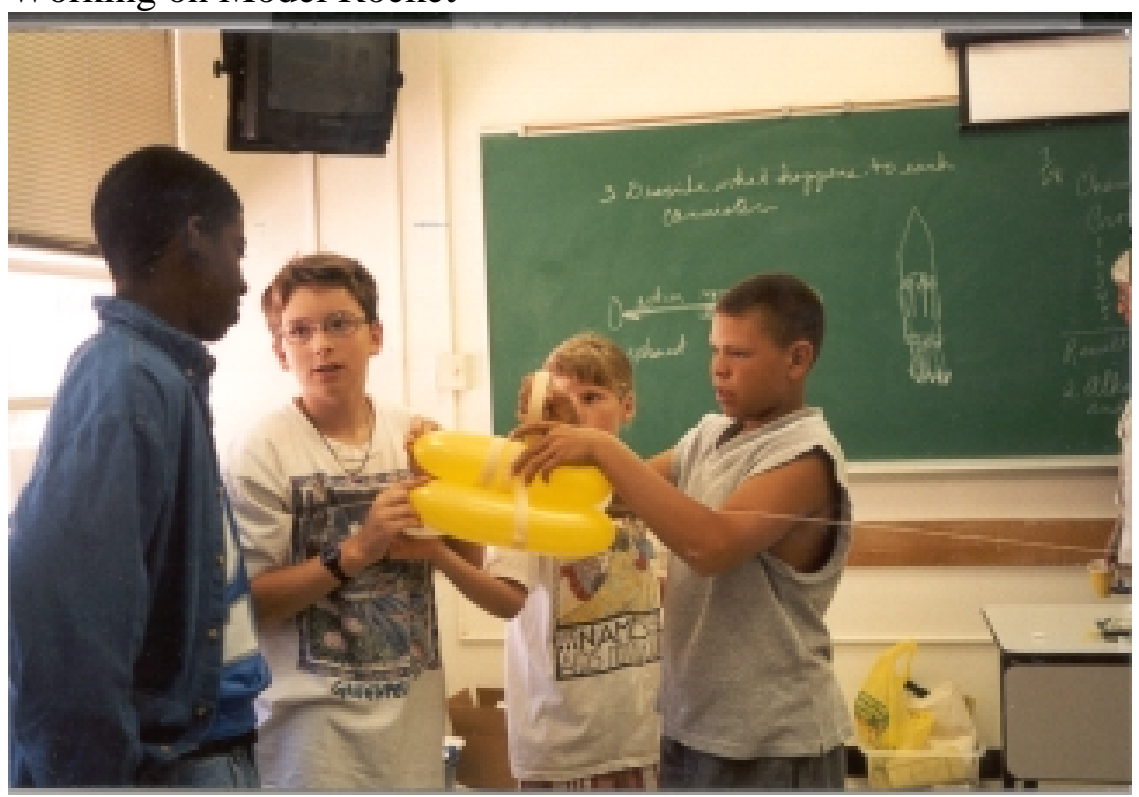

two purposes: to improve the public image of the University of New Mexico's School of Engineering and College of Arts and Sciences, and to increase awareness of opportunities in EMS disciplines. Currently, the MEMS project provides various types of support (either financial or with actual resources) for pre-college initiatives. This Section will provide a brief summary of these projects.

The Saturday Math and Science Academy is a program consisting of a series of 18 six-hour workshops for 50 elementary school children designed to teach them fundamental concepts in Mathematics, Science and Engineering through hands-on projects in Lasers, Chemical Engineering, Fluid Dynamics, Structural Dynamics, Biology and Physics. Some of the projects that students work on are; bridge building, solar panel cars and model rockets (see Figures 12 and 13). The target populations for this project are African American as well as other minorities and at-risk youth. UNM engineering, mathematics and science students are hired to assist in this project. This project has been in existence since 1988. In a recent survey to UNM freshman engineering students, $2 \%$ cited this project as having a major impact on their decision to become an engineer. This is impressive considering the size of the program and the short duration for which it has been in existence. 
Figure 14. Student from Mobile Science Academy Working on Project

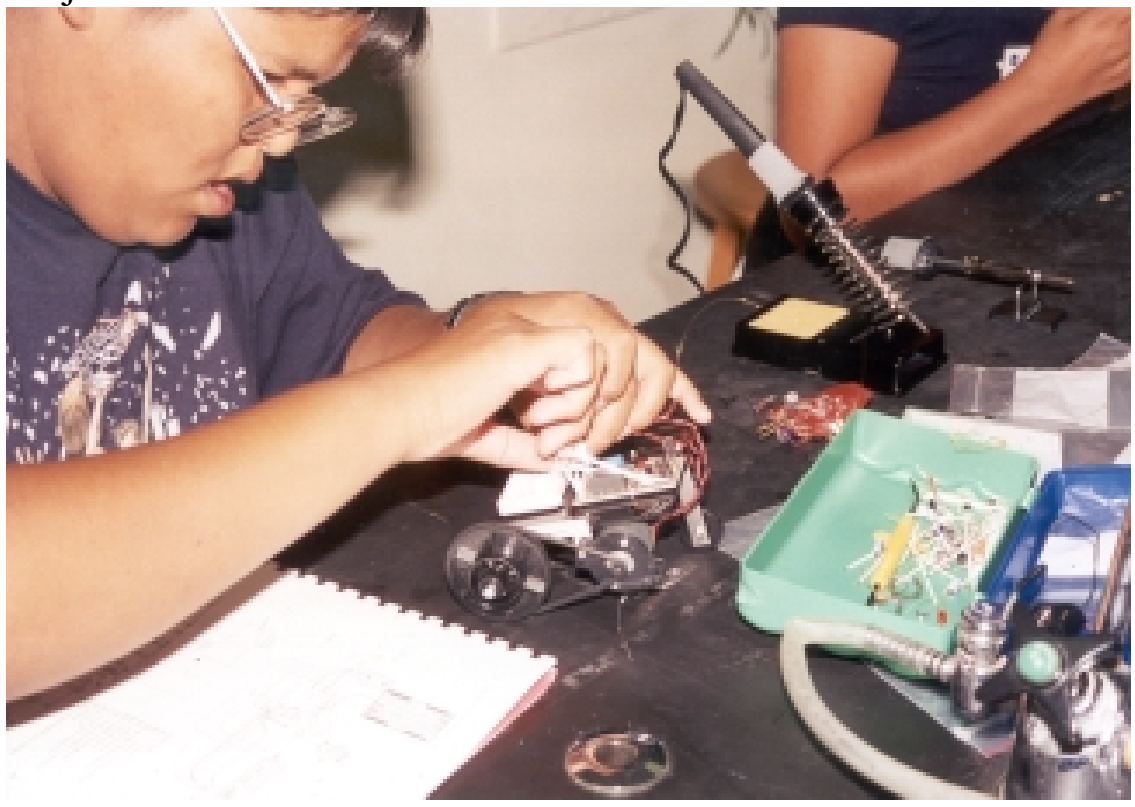

Figure 15. Student from Mobile Science Academy Working on Project

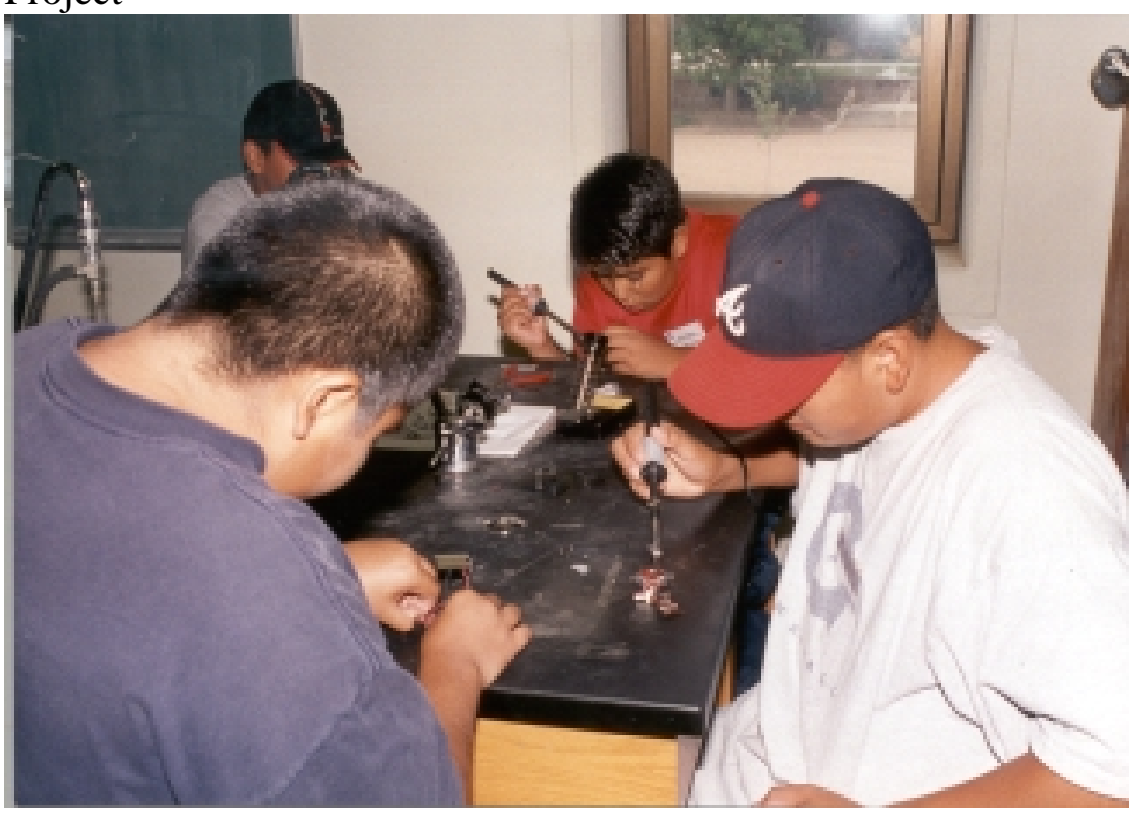

The Mobile Science Academy is a program, out of the College of Santa Fe, Santa Fe, New Mexico, that moves from reservation to reservation to help Native American elementary school children develop award winning mathematics, science and engineering projects. Students in this program learn basic mathematical and scientific concepts for their individual projects and are taught basic presentation skills (see Figure 14 and 15).

The Hispanic Engineering Science Organization (HESO), the American Indian Science and Engineering Society (AISES) and the National Society of Black Engineers (NSBE) are student organizations housed in the UNM School of Engineering. Each of these organizations has MEMSsponsored outreach activities for middle and high school students to encourage them to consider engineering, mathematics and science careers. The student organizations bring middle and high school students to campus for a day and involve them in activities that require them to use engineering, mathematics and science concepts in assigned projects: bridge building, car racing, egg drop, and technical writing competitions. 
The NASA Space Camp project brings teachers and elementary students together into a teaching environment where teachers gain actual classroom experience in new and innovative teaching methodologies for elementary school teachers. Teachers are trained to teach basic engineering, mathematics and scientific principles and showed how to use these in the development of a project. Teachers are then placed in a classroom environment where they assign scientific or engineering design projects to their students and teach the necessary scientific principles to carry out their assignments.

NASA Secondary Mathematics and Science program provides scholarships to College of Education students pursuing a Bachelors degree in secondary mathematics and science who are planning to teach at a disadvantaged or minority-serving secondary public or reservation school in New Mexico. Students in this program are required to do a co-op, if offered, with NASA where they work on the same type of projects that any other engineering, mathematics or science student would. The purpose of this project is to increase the number of highly qualified mathematics and science teachers at disadvantaged secondary schools.

The Alliance for Minority Participation (AMP) Southwestern Indian Polytechnic Institute (SIPI), Technical Vocational Institute (T-VI), UNM Valencia and UNM Los Alamos collaborations are a group of joint efforts with two-year post-secondary institutes designed to increase the transfer of EMS students from these institutes to UNM and retain them. Initial research into minority preparation demonstrates that a disproportionate number of Native Americans, African Americans and Hispanics come to UNM inadequately prepared to begin in an EMS curricula and require much remedial work prior to this. Figure 15 shows that $23.1 \%$ of Native American; 25\% of African American and 17.5\% of Hispanic incoming freshman engineering students achieve below 18 on the Math-ACT exam; only $3.9 \%$ of Whites and $0.0 \%$ of Asians perform in this range (see Figure 16). In this study, 0\% of Native American; 0\% of

Figure 16. Performance on Math-ACT by Ethnicity (Fall 1997 Incoming Freshman Engineering Class)

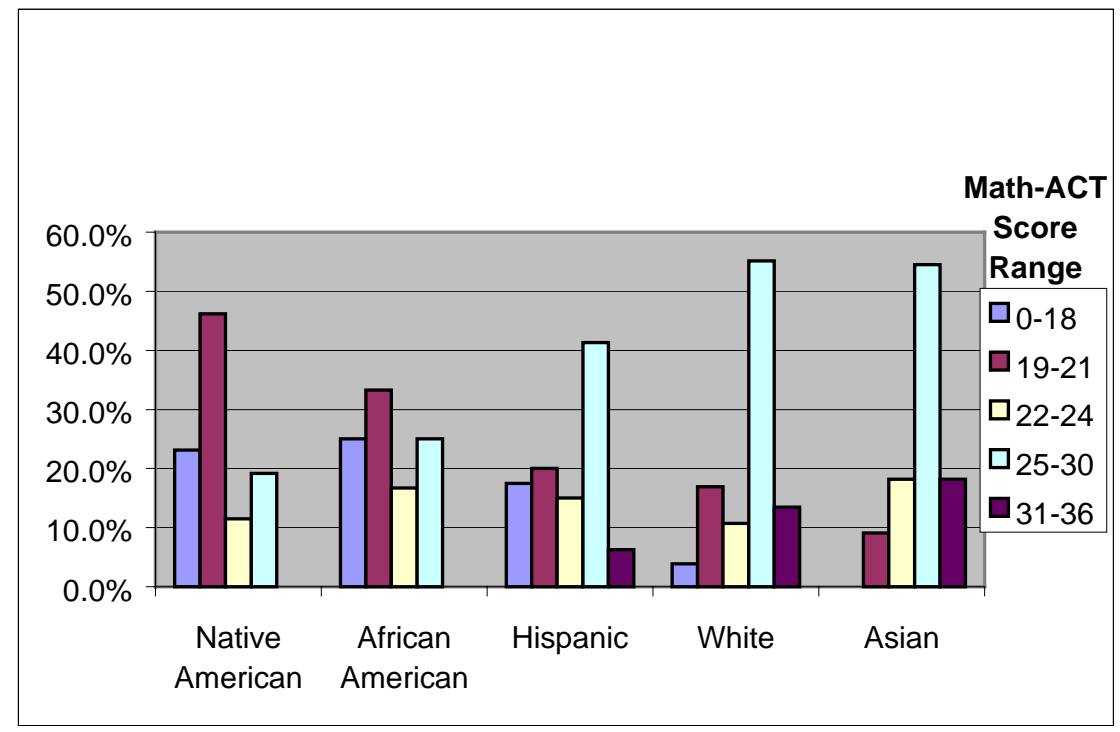

African American and $6.3 \%$ of Hispanic students achieved math-ACT scores greater that 31 as opposed to $13.5 \%$ of Whites and $18.2 \%$ of Asians. For this reason, many underrepresented minorities choose to attend two-year institutes prior to entering UNM.

In Fall 1999, MEMS received additional funding to expand this project to include the other institutes serving other minority populations. This section will focus primarily on 
Figure 17. Trends for Native American Enrollment within UNM's School of Engineering

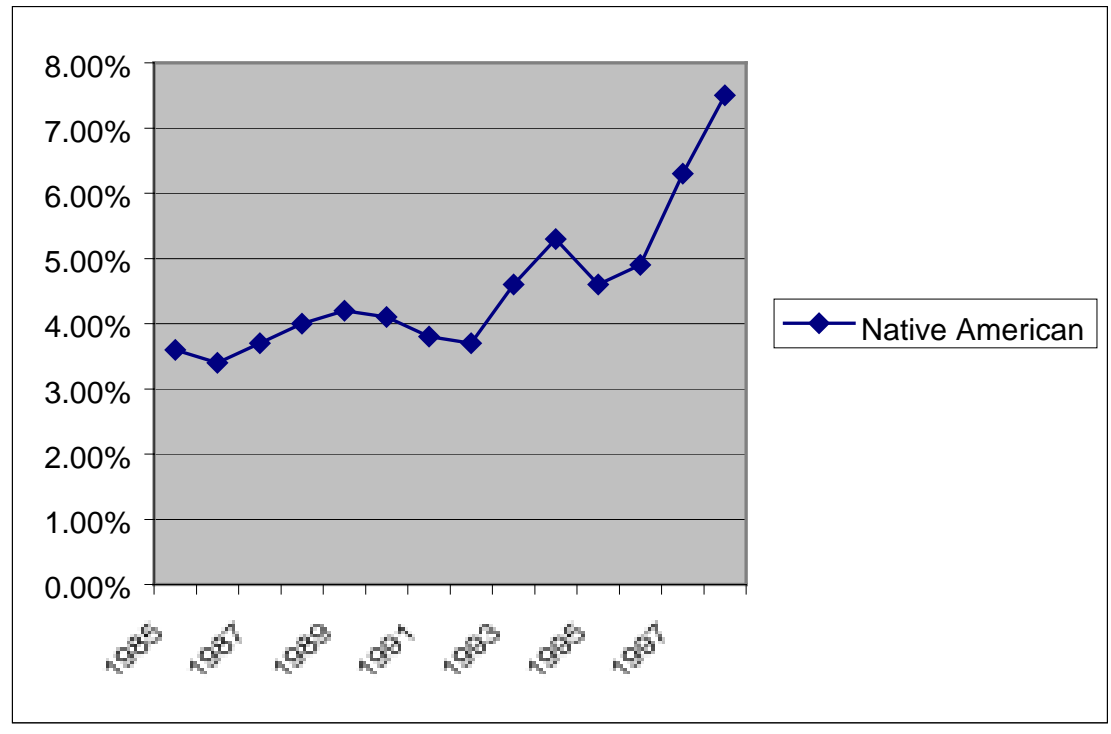

the AMP SIPI portion of the collaboration since this is the one that we have more experience with.

In an informal survey of transfer students from various two-year institutes from throughout New Mexico, we found that the biggest problem transfer students have is transition. The AMP SIPI program was designed to address this by promoting awareness of students' educational needs, creating publications to assist transfer students, informing students about workshops, funding and scholarship opportunities, announcements and unique activities through email, telephone conversations and letter writing. Prior to this initiative, there was little or no information going out to SIPI students about pursuing engineering, mathematics and science degrees.

Every year, 15 UNM students are selected to serve as mentors for 15 potential transfers from SIPI. The program consists of an orientation to disseminate a wide range of technical, policy and course information and two three-day workshops to help improve the quality of students study skills, networking skills and to increase their comfort level with the university environment. One semester before these students transfer to UNM, they are invited to take Engineering 116 and another course of their choice, at UNM, at no cost to help them become acquainted with AEW study groups and the university environment.

Prior to this program, there was no transfer program with SIPI; through informal surveys, we are certain that there were very few transfers from SIPI prior to this program. Since the project began, we have had 11 Native Americans transfer from SIPI to UNM's School of Engineering; currently, that is $10 \%$ off the Native American population within the School of Engineering.

Because of the many programs at UNM, the AMP SIPI program being one, UNM's School of Engineering has seen a steady increase in Native American enrollments. Native American engineering enrollments have increased from around 4\% before 1993 to over $7 \%$ after 1998 .

The Rio Grande and Valley Cluster Programs are partnerships among the individual clusters, the UNM MEMS program and the UNM HESO student organization designed to increase the number of minorities matriculating into the University of New Mexico seeking degrees in EMS disciplines. The Rio Grande cluster partnership is a recent effort consisting of AEW study 
groups at Rio Grande High school and Harrison Middle School facilitated by UNM engineering, mathematics and science students. This project is based on the MEMS/Valley High School partnership and is in its developmental stages. Both Rio Grande and Valley High Schools are predominantly minority schools (greater than $70 \%$ minority).

The Valley High School (VHS) cluster partnership with the UNM MEMS program is a precollege program called the Valley Academy. In 1989, VHS received funding from General Electric (GE) to create the Valley Academy to promote academic excellence and encourage high school students to continue their education upon graduation from high school at a post-secondary institution. The goal of the program was to double the number of VHS students going onto postsecondary schools within 5 years. Valley Academy achieved this goal in 3 years by increasing the number of students going on to post-secondary institutes from $22 \%$ to $46 \%$.

This program consists of UNM students facilitating AEW study groups at VHS primarily in math, science and technology and UNM faculty training Valley faculty in math, science and technology. To date, UNM faculty have trained VHS faculty in Calculus as well as in the use of graphing calculators. As a result of this wise investment, VHS has developed an excellent infrastructure to support academic excellence in many subjects including mathematics and science.

All VHS students are invited to participate in the Valley Academy and if accepted into the program must adhere to a strict set of requirements. Valley Academy students are required: to select a major and a minor (courses in the major are to be taken each of the student's four years); during junior and senior years students are encouraged to take Advance Placement Tests for college credit; students are required to participate in a school activity and community service during each school year; students agree to put forth an effort to improve attendance each year, to take advantage of opportunities offered to them and to improve or maintain their grade point average each year. The Valley Academy provides the following pre-college services as well: accelerated curriculum, special preparation for college entrance exams (PSAT, PLAN and ACT), college search services, job shadowing opportunities and AEW workshops.

As a result of this effort, from 1989 to present, Valley Academy has increased the number of Valley High School graduates pursuing post-secondary education from $22 \%$ to $73 \%$ (Spring 1999 data). Recently, GE chose the Valley Academy as a model program and now requires that all GE funded pre-college programs in the nation use the Valley Academy model. The following is a summary of some of the successes of the program:

- VHS is the only public Magnet School with in the Albuquerque Public School system,

- 244 students out 450 seniors are taking Advanced Placement classes for college credit at VHS this year,

- The number of students who participate directly in the Valley Academy has increased from 196 in 1988 to 1160 in 1999 (52.7\% of VHS student body), and

- Successful spin-offs to feeder schools; Garfield and Taft Middle Schools currently have pre-academy programs to prepare middle school students for high school. 


\section{Evaluation}

Having a systematic means for evaluating program design, function, and delivery is essential in providing high-quality, accessible services to ensure efficient and effective allocation of resources and to ensure outcomes are consistent with the goals and objectives of the program. In 1991, initial data analysis indicated that minority enrollment and graduation rates were inconsistent with the demographics of the state and that minority students were failing key gateway courses in engineering, mathematics and science curriculum at a much higher rate than non-minority students. Further analysis demonstrated that under-represented minorities did not come to UNM with the same academic preparation as non-minorities. This led to the initial design, development and implementation of the MEMS program.

In the initial project design, MEMS staff were careful to insure that evaluation was an integral part of the overall program. In 1994, a faculty advisory council consisting of engineering, mathematics and science faculty was formed to assist in defining program goals and objectives, to provide feedback, and to assist in outcomes assessment of the project. In 1996, an industrial advisory council consisting of representatives from key corporations and government organizations with a vested interest in UNM, was formed to provide similar services but from an industry/government perspective. This gives industry and government the opportunity to promote changes in the university culture by increased involvement in program analysis, development and implementation.

The following reports were designed to provide feedback to the faculty and industrial advisory councils and MEMS staff on program performance and evolution: course retention and GPA comparison data of MEMS AEW students versus others (see Figures 10 and 11); semester and cumulative GPA comparison data of MEMS AEW and Engineering 116 students (see Section IV, Program Components, Sub-section, Scholarships, Paragraph 3); Engineering 116 and AEW usage measured by average attendance; and many surveys to participants of all programs to assess the changing needs of minority engineering students. These reports are updated every semester and help us to adjust and modify the program as we go along to improve access and quality. On a yearly basis, MEMS provides the following reports: 1, 2, 3 and 4-year retention rates of MEMS Summer Bridge Students (see Figure 7), and trends for minority enrollment and graduation rates (see Figure 18).

MEMS, periodically, provides other reports to assess changes taking place in UNM student populations: Math-ACT scores, both semester and longitudinal trends (see Figures 1, 2 and 16); longitudinal trends for cumulative and semester GPA's; demographic studies (see Section II, Background Information, Paragraph 2); academic preparation of freshman engineering students (see Section II, Background Information, Paragraphs 3 through 8); case studies on individual students (see Section VII, Future Problems); etc.... A good evaluation system allows staff to continually troubleshoot and correct problems in overall program design, functionality and quality. Invariably, these changes give rise to new questions that in turn give rise to needs for new analysis. 


\section{Summary}

Since MEMS started, minority enrollment at UNM's School of Engineering has increased from less than $30 \%$ before 1990 to more than $40 \%$ in 1999. Engineering B.S. degrees earned by UNM minority students have increased from $20 \%$ of the total in 1992 to $40 \%$ in 1999 (see Figure 18, below). Summer Bridge along with the AMP SIPI and AMP T-VI collaborations and the Rio Grande/Valley high school cluster programs give UNM the opportunity to recruit high-caliber minority students from throughout New Mexico. MEMS staff have a methodical and welldocumented means in place for evaluating program performance. Over a six-year period, MEMS staff have gathered data that has systematically been used to continually modify program components to improve over-all quality. With faculty and industry advisory councils overseeing and assisting in analysis and evaluation of program components, MEMS has established itself as an institutional model for minority retention, recruitment, and excellence.

Figure 18. Minority Engineering Enrollment \& Degree Trends at UNM

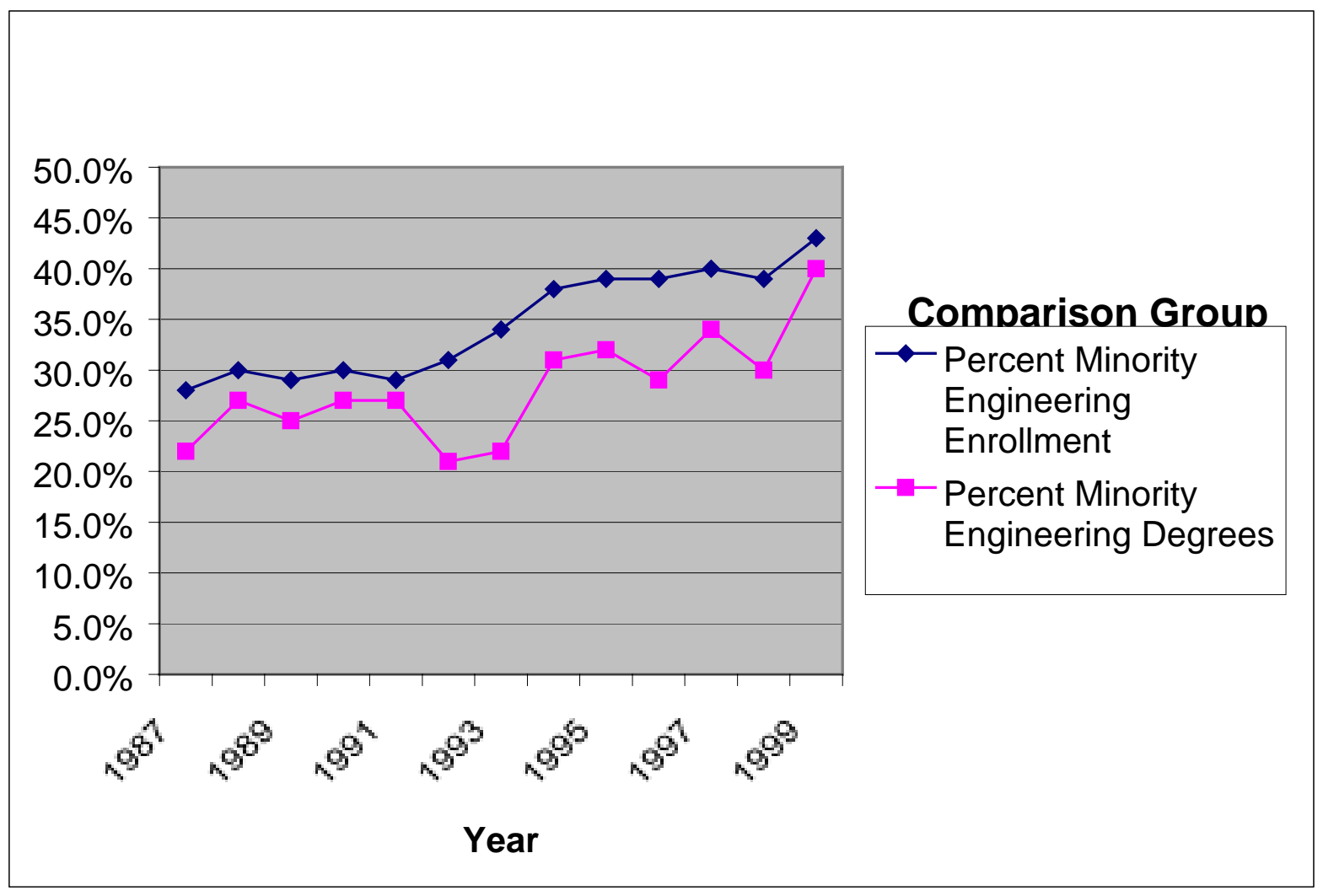

VII. Future Problems

The MEMS program has created the type of program that will increase minority retention and graduation in EMS disciplines (see Figure 18, above). As a consequence of our extensive research, we have developed a better understanding of obstacles that under-represented minorities encounter when pursuing an EMS degree. With a predicted shortage of 100,000 
engineers in the United States every year, the question arises: Can minority education play a role in lowering this shortage? What can we do to increase minority participation in engineering, mathematics and science? We found that the two biggest obstacles for minority students are financial need and academic preparation. This section presents a case study and a survey to generate future discussion on problems and potential solutions.

Table 3, below, is a case study of a Native American student from the Acoma Pueblo reservation in New Mexico. This student came to UNM with a Math-ACT score of 15, an overall CompACT score of 13 and high financial need. When this student arrived at UNM, he joined the MEMS program and did very well for himself. Based on Math-ACT scores, many academic counselors would advice students, with similar backgrounds, not to pick a math-intensive major. There are always a percentage of students with low Math-ACT scores who succeed even without any intervention, although; as Math-ACT scores drop below 20 the percentage of students succeeding in an EMS discipline declines.

Math-ACT scores are good statistical tools but useless indicators for potential. If educators are to increase the number of BS degrees in EMS disciplines, educators need to come up with a more accurate measure to predict potential for success and find mechanisms to retain students who fall within this measure. What do we have to do to retain students once we recognize potential for success? As a university, how can we impact public schools to insure that minority students are better prepared when they arrive at UNM? How do we integrate the university culture into local communities to create a seamless transition from elementary to middle school, from middle to high school and from high school to UNM?

In a survey, minority engineering students were asked questions and provided responses as follows:

Why does such a disparity exit in minority academic preparation?

- Teachers are not accustomed to minorities and are not used to working with them,

- Teachers are more comfortable working with non-minorities,

- Students have to go to teachers to get help,

- Struggling students are ignored.

Why do Asian minorities do so well?

- They get a lot of special attention from teachers because they're supposed to be smarter. Who played the biggest role in your education?

- My mother always emphasized the importance of education,

- I wanted something better for myself than what my parents had,

- Competition with other students, when I saw other students getting good grades I wanted to do better than them,

- I was placed in advanced classes,

- As a result of the Valley Academy, I was required to maintain a GPA greater than 3.0,

- Parents encouragement.

Were you involved in any pre-college programs?

- Kids are not informed about opportunities, the only way they find out about opportunities is if other kids tell them,

- Yes but they are just there in name, they don't do anything. 
Table 3. Student nUmber: \#\#\#-\#\#-\#\#\#\# StUdent nAME: XXXXXXX, XXXXXXXXX XXXXXXXx

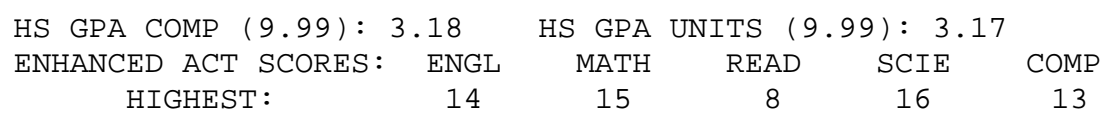

FALL 1990 UNIVERSITY COLLEGE

CHEM 111 ELEM OF GEN CHEM

RTADING ADVANCEMENT CR

MATH 120 INTERMEDIATE ALGEBRA CR

SEM. GPA $=3.00$ EARNED HRS $=7$

CUM. GPA $=3.00$ EARNED HRS $=7$

SPRING 1991 UNIVERSITY COLLEGE

ENGL 101 WRTG W/RDGS IN EXPOS C+ 3

$\begin{array}{lllll}\text { MATH } & 123 & \text { TRIGONOMETRY } & \text { B } & 2 \\ \text { MATH } & 150 & \text { ADV COLLEGE ALGEBRA } & \text { A } & 3\end{array}$

MUSIC 140 MUSIC APPRECIATION B 3

P E-NP 101 BEGINNING SWIMMING A 1

SEM. $\mathrm{GPA}=3.16$ EARNED HRS $=12$

CUM. GPA $=3.12$ EARNED HRS $=19$

FALL 1991 UNIVERSITY COLLEGE

$\begin{array}{lllll}\text { CHEM } & 121 & \text { GENERAL CHEM } & \text { C } & 4 \\ \text { MATH } & 162 & \text { CALCULUS I } & \text { C } & 4 \\ \text { P E-NP } & 101 & \text { SWIMMING } & \text { A } & 1 \\ \text { PSYCH } & 105 & \text { GEN. PSYCHOLOGY } & \text { C- } & 3 \\ & \text { SEM. GPA }=2.08 & \text { EARNED HRS }= & 12 \\ & \text { CUM. GPA }=2.67 & \text { EARNED HRS }= & 31\end{array}$

SPRING 1992 UNIVERSITY COLLEGE

$\begin{array}{lllll}\text { CHEM } & 122 & \text { GENERAL CHEM } & \text { C } & 4 \\ \text { ENGL } & 102 & \text { COMP: ANAL \& ARG } & \text { C+ } & 3 \\ \text { GEOG } & 101 & \text { GEOGRAPHY } & \text { WP } & 3 \\ \text { MATH } & 163 & \text { CALCULUS II } & \text { C } & 4 \\ \text { P E-NP } & 170 & \text { VOLLEYBALL } & \text { A+ } & 1 \\ & \text { SEM. GPA }=2.27 & \text { EARNED HRS }= & 12 \\ & \text { CUM. GPA }=2.55 & \text { EARNED HRS }= & 43\end{array}$

FALL 1992 UNIVERSITY COLLEGE

\section{ART HI 101 INTRO TO ART C+}

ENGR-F 122 INTRO ENGR METH A-

MATH 163

P E-NP 162

CALCULUS II

JOGGING FITNESS

P E-NP 170 VOLLEYBALI

SEM. GPA $=3.08$ EARNED HRS $=8$

CUM. GPA $=2.67$ EARNED HRS $=54$

SPRING 1993 BACHELORS: ENGINEERING

ECON 200 PRINC \& PROBS B 3 ED FDN 124

CMPTR AWARE ED A+ 1

$\begin{array}{lllll}\text { MATH } & 264 & \text { CALCULUS III } & \text { C+ } & 4 \\ \text { MUSIC } & 271 & \text { MUSIC TODAY } & \text { B } & 3 \\ \text { E-NP } 148 & \text { ARCHERY } & \text { A } & 1 \\ \text { PHYSCS } & 160 & \text { GENERAL PHYSICS } & \text { C+ } & 3 \\ \text { PHYSCS } & 167 & \text { PROB GEN PHYSICS } & \text { CR } & 1 \\ & \text { SEM. GPA }=2.90 & \text { EARNED HRS }= & 16 \\ & \text { CUM. GPA }=2.72 & \text { EARNED HRS }=70\end{array}$

\begin{tabular}{lccccr}
\multicolumn{1}{c}{ FALL } & 1993 & BACHELORS : & ENGINEERING \\
C E & 202 & ENG STATICS & C & 3 \\
C E & 281 & ENGR MEAS/LAB & C & 2 \\
MATH & 316 & ORD DIFF EQUAS & B & 3 \\
MUSIC & 139 & MUSIC APPRECIATION & A & 3 \\
P E-NP & 102 & SWMMING & A & 1 \\
& & SEM. GPA $=2.91$ & EARNED HRS $=$ & 12 \\
& & CUM. GPA $=2.75$ & EARNED HRS $=$ & 82
\end{tabular}

\begin{tabular}{|c|c|c|c|}
\hline & PRING & BACHELORS : & ENGINEE \\
\hline $\mathrm{CE}$ & 252 & APPL CIVIL ENGR & B \\
\hline $\mathrm{C} E$ & 270 & CONSTR MATERIALS & $\mathrm{B}+$ \\
\hline $\mathrm{E}$ & 306 & DYNAMICS & $\mathrm{C}+$ \\
\hline $\mathrm{ATH}$ & 314 & LINEAR ALG & $B+$ \\
\hline $\mathrm{E}-\mathrm{NP}$ & 102 & SWMMING & CR \\
\hline \multirow{3}{*}{ PHYSCS } & 161 & GENERAL PHYSICS & C \\
\hline & SEM. & $\mathrm{GPA}=2.71 \quad$ EARNED & HRS $=$ \\
\hline & CUM. & $A=2.75 \quad$ EARNED & HRS $=$ \\
\hline
\end{tabular}

\begin{tabular}{llllllr} 
& \multicolumn{1}{c}{ FALL } & 1994 & \multicolumn{3}{c}{ BACHELORS : ENGINEERIN } \\
C & E & 302 & MECH OF MATERIALS & C & 3 \\
C & E & 303 & MECH OF MATER LAB & B + & 1 \\
C & E & 331 & FLUID MECHANICS & B & 4 \\
C & E & 350 & ENG ECONOMY & C+ & 3 \\
P & E-NP & 160 & WGHT TRNG & A & 1 \\
P & E-NP & 163 & WGHT TRAINING & A & 1 \\
& & & SEM. GPA $=2.79$ & EARNED HRS $=$ & 13 \\
& & & CUM. GPA $=2.75$ & EARNED HRS $=109$
\end{tabular}

SPRING 1995 BACHELORS: ENGINEERING

C E 282 GEOM TRANS SYS/LAB B- 2

$\begin{array}{lllll}\text { C E } & 308 & \text { STRUCT ANALYSIS } & \mathrm{C}+ & 4\end{array}$

$\begin{array}{llllll}\text { C E } & 310 & \text { STRUCT } & \text { DESIGN I } & \text { C } & 4\end{array}$

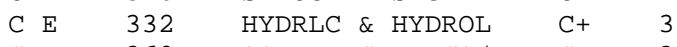

C E 360 SOIL MECHANICS/LAB C+ 3

SEM. GPA $=2.29$ EARNED HRS $=16$

CUM. GPA $=2.69$ EARNED HRS $=125$

$\begin{array}{lllllll} & & \text { FALL } & 1995 & \text { BACHELORS : ENGINEERIN } \\ \text { C E } & 370 & \text { ENGR MATERIALS SCI } & \text { B } & 3 \\ \text { C E } & 382 & \text { TRANS ENGR } & \text { C+ } & 3 \\ \text { C E } & 430 & \text { HYDRAULIC SYSTEM } & \text { WP } & 3 \\ \text { C E } & 435 & \text { WTR \& WASTEWTR } & \text { C- } & 3 \\ \text { PHYSCS } & 262 & \text { GENERAL PHYSICS } & \text { WP } & 3 \\ & & \text { SEM. GPA }=2.33 & \text { EARNED } & \text { HRS }= & 9 \\ & & & \text { CUM } & \text { GPA }=2.67 & \text { FARNED HRS }= & 134\end{array}$

CUM. GPA $=2.67$ EARNED HRS $=134$

SPRING 1996 BACHELORS: ENGINEERING

$\begin{array}{llllll}\text { C } & \text { E } & 424 & \text { STRUC DESGN } & \text { A } & 3 \\ \text { C } & \text { E } & 433 & \text { GROUNDWATER } & \text { B- } & 3\end{array}$

$\begin{array}{lllll}\text { C } & \text { E } & 472 & \text { CONSTR CONTR } & \text { B- } 3\end{array}$

$\begin{array}{lllll}\text { C E } & 490 & \text { PROF PRACTICE } & \text { B } & 1\end{array}$

$\begin{array}{lllll}\text { C E } & 499 & \text { DESIGN SYSTEMS } & \text { C } & 3\end{array}$

PHYSCS 262 GENERAL PHYSICS B 3

SEM. GPA $=2.89$ EARNED HRS $=16$

CUM. GPA $=2.69$ EARNED HRS $=150$

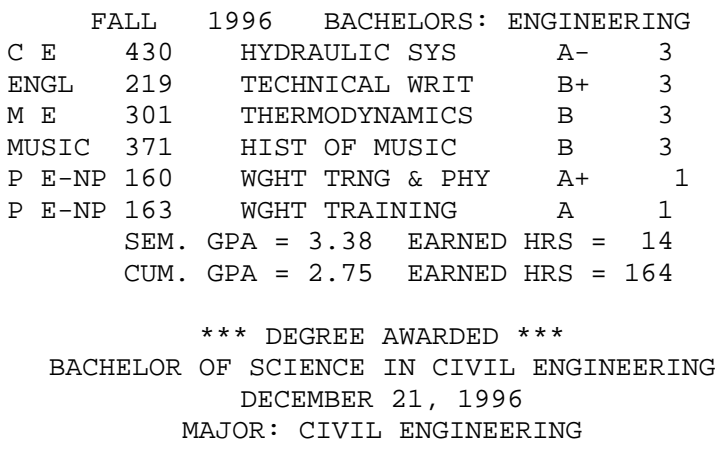


Comments on the survey were as follows:

- Depending on the confidence level of a student, a teachers attitude can either be devastating for students with low confidence or it can be motivating and make students want to try a lot harder,

- University faculty don't care,

- Don't have time to really learn at UNM,

- Wish high school was more challenging, it was to easy,

- Kids do not know what they have to do to prepare for college,

- I didn't learn anything in chemistry,

- English is horrible in the public school systems.

What do you think are the solutions to minority education?

- You have to learn to do things for yourself, you can't always wait for people to do things for you,

- Students can't use being a minority as an excuse.

\section{Acknowledgment}

The authors would like to acknowledge all the people who have made this research possible. A project like this requires support from university administrators at all levels. We would like to give particular thanks to President Bill Gordon and the Deans of the School of Engineering and the College of Arts and Sciences, Paul Fleury and Michael Fischer, respectively, for their support in seeking funding from the New Mexico State Legislature. We would like to give thanks to the multitude of university faculty and department chairs that support the project with time and resources, especially, those that sit on the MEMS faculty advisory council.

We would like to give thanks to all the sponsors from the corporate and government sector that support the program through time and resources: the National Aeronautics and Space Administration (NASA), the New Mexico State Legislature, the US Department of Defense, Ford Motor Company, the General Electric Fund, IBM, Intel Corporation, the New Mexico Alliance for Minority Participation, the Arizona Western Alliance for Expanded Student Opportunities, Union Pacific, Boeing, Honeywell, Celanese, General Motors, the ARCO Foundation, Texas Instruments, Hewlett Packard, Lucent Technologies, Sandia National Laboratories, Los Alamos National Laboratories and the UNM High Performance Computing Center.

We would like to thank the members of the New Mexico Commission on Higher Education (CHE) for their tremendous support through the years and a special thanks to the Director of the CHE, Bruce Hamlett. We would like to thank the Honorable Sheryl Williams, Representative, NM State Legislature and Honorable Ted Hobbs, Representative, NM State Legislature for their support.

We would like to thank individual people for their personal contributions of time and resources: Kenneth Kraft, Lucent Technologies; Dion McInnis, Development SOE; Ernie Herrera, Frank Gilfeather and Chris Maestas, UNM High Performance Computing Center; Ricardo Maestas, Associate Dean of University College; Michael Lee, MEP Director, University of Missouri; 
Walter Gerstle and Gabe Lopez, Faculty, UNM SOE; and Terry Holmberg, Valley Academy, VHS.

We would like to thank UNM staff for their contributions as well: Maurice Thompson, Assoc. Dir., NASA Training Project (NTP); Marco Romero, MEMS Senior Tutor; Katherine Love, Admin. Assistant, MEMS; Susan Sandoval, Admin. Assistant, MEMS and NTP; Doug Williams, Admin. Assistant, NTP; and Carolene Whitman, Program Coordinator, AMP SIPI.

\section{Bibliography}

Adams, H. (1992). Academic Gamesmanship: Becoming a "Master" Engineering Student. National Action Council for Minorities in Engineering, New York, NY.

Adams, H. (1993). Focusing on the Campus Milieu: A guide for Enhancing the Graduate School Climate. National Center for Graduate Education for Minorities, Notre Dame, Indiana.

Balkcom, S. (1992). Cooperative Learning. Education Research Consumer Guide, n1 Jun 1992. Office of Education Research and Improvement (ED), Washington, DC. URL: http://www.ed.gov/pubs/

Gokhale, A. (1995). Collaborative Learning Enhances Critical Thinking. Journal of Technology Education, Volume7, Number 2. URL: http://scholar.lib.vt.edu/ejournals/JTE/v7n1/contents.html

Hudspeth, M.C. (1992). A Handbook for Academic Excellence Workshops. Pomona, CA: California State Polytechnic Institute.

Jacques, D. (1984). Learning in Groups. Gulf Publishing Company, Houston, Texas.

Landis, R. B. (1995). Studying Engineering: A Road Map to a Rewarding Career. Discovery Press, Burbank, California.

Smyser, B. M. (No Date). Active and Cooperative Learning. [WEB document only] URL: http://www.wpi.edu/ isg_501/bridget.html

Treisman, P. U. (1983). Improving the performance of minority students in college-level mathematics. Innovation Abstracts, 5(17), 1-5.

\section{Biography}

JOSEPH D. TORRES

Joseph Torres received a Bachelor of Science in Electrical Engineering (1984), a M.S. in Mathematics (1986) and a $\mathrm{Ph} . D$. in Mathematics (1991) from the University of New Mexico and is the current Director of the Minority Engineering, Mathematics and Science (MEMS) Program. He has taught courses in the Department of Mathematics, the Department of Electrical Engineering and the School of Engineering at UNM since 1987 to present. He has been responsible for designing and developing many of the retention strategies that are currently in place at UNM; taking programs and projects from their initial conceptual stages, to fundraising for these project to the final implementation and management of the project. He has developed expertise in the area of databases and data analysis that has been critical in evaluating MEMS progress. 


\section{TOM CUMMINGS}

Tom Cummings has worked in minority education for over thirty years. In 1965, he worked with the Navajo community of Nenahnezad to set up a Headstart program. From 1966 to 1970 he headed the US Office of Economic Opportunity in western New Mexico. From 1970 to 1978, he worked at Ramah Navajo High School; since 1979, he's been with University of New Mexico's Minority Engineering Programs. 